\title{
Recycling of poly(ethylene terephthalate) - A review focusing on chemical methods
}

\author{
B. Geyer ${ }^{1}$, G. Lorenz $^{1,2}$, A. Kandelbauer ${ }^{1,2^{*}}$ \\ ${ }^{1}$ Reutlingen Research Institute (RRI), Reutlingen University, Alteburgstrasse 150, 72762 Reutlingen, Germany \\ ${ }^{2}$ School of Applied Chemistry, Reutlingen University, Alteburgstrasse 150, 72762 Reutlingen, Germany
}

Received 27 November 2015; accepted in revised form 8 February 2016

\begin{abstract}
Recycling of poly(ethylene terephthalate) (PET) is of crucial importance, since worldwide amounts of PETwaste increase rapidly due to its widespread applications. Hence, several methods have been developed, like energetic, material, thermo-mechanical and chemical recycling of PET. Most frequently, PET-waste is incinerated for energy recovery, used as additive in concrete composites or glycolysed to yield mixtures of monomers and undefined oligomers. While energetic and thermo-mechanical recycling entail downcycling of the material, chemical recycling requires considerable amounts of chemicals and demanding processing steps entailing toxic and ecological issues. This review provides a thorough survey of PET-recycling including energetic, material, thermo-mechanical and chemical methods. It focuses on chemical methods describing important reaction parameters and yields of obtained reaction products. While most methods yield monomers, only a few yield undefined low molecular weight oligomers for impaired applications (dispersants or plasticizers). Further, the present work presents an alternative chemical recycling method of PET in comparison to existing chemical methods.
\end{abstract}

Keywords: recycling, poly(ethylene terephthalate), degradation, monomers, oligomers

\section{Introduction}

From the late 1990s to the year 2011, the worldwide amount of poly(ethylene terephthalate) (PET) increased rapidly from approximately 14 to 60 million tons $[1,2]$. Correspondingly, equivalent amounts of PET-waste are generated. Since life cycle assessment studies showed that re-utilization of PET has a positive effect on energy balance and the reduction of $\mathrm{CO}_{2}$ emissions, for ecological reasons, the need of an appropriate PET-recycling is greater than ever [3-7]. Thus, several PET-recycling methods have been developed, which were partially reviewed in the literature [8-15].

One of these methods is the incineration of the PETwaste using the released heat of combustion (direct energy recovery), which amounts to about $46 \mathrm{MJ} \cdot \mathrm{kg}^{-1}$ $[13,14]$. Another method, the pyrolysis of the PET- waste is applied to produce a substitute of coal (carbonization) or aromatic and aliphatic compounds as an alternative for fossil fuels (indirect energy recovery). These applications are classified as energetic recycling, since they both use the released thermal energy either directly from incineration of the PETwaste or indirectly from combustion of pyrolysis products [16-31].

For material recycling, the PET-waste is used as an additive in crushed form. In this application, it acts as a partial substitute of natural raw materials such as sand and other natural aggregates and helps reducing the consumption of such resources. It is mixed into composite materials (e.g. asphalt, mortar or concrete) or other polymers to improve their mechanical properties [32-65].

\footnotetext{
${ }^{*}$ Corresponding author, e-mail: andreas.kandelbauer@reutlingen-university.de (C) BME-PT
} 
Thermo-mechanical recycling represents another method of re-utilization of PET-waste. Generally, the PET-waste is re-melted without additives. Since this procedure leads to a downcycling of the material due to discoloration or thermal degradation, it is also remelted with specific additives (complementary colors, inorganic materials or epoxy-chain extenders) to prevent the downcycling [66-94].

In this review, downcycling is used in various meanings. In a strict sense, downcycling means the deterioration of the material properties of PET by damaging or shortening the polymer chains of the polyester. However, processes leading to the utilization of PET in low value applications such as a filler material where the material potential of PET is not fully used can also be considered as some kind of 'downcycling' in a wider sense. Ultimately, thermal degradation processes like incineration, pyrolysis or carbonization which lead to monomers and hence a total loss of efforts for synthesis for virgin PET can also be considered as 'downcycling'. Hence, most energetic and material recycling methods ultimately lead to a downcycling of PET.

In contrast, chemical recycling methods offer the possibility of re-introduction of PET into the material cycle without loss of quality by de-polymerizing PET-waste into monomers. These monomers are used for re-polymerization. Most frequently applied methods use water (hydrolysis), glycols (glycolysis), amines (aminolysis) and alcohols (alcoholysis) for de-polymerization of PET-waste under various reaction conditions. However, these methods require high temperature and high pressure conditions as well as considerable amounts of solvents and degrading agents for de-polymerization [95]. Further, chemical recycling methods generally entail separation and purification steps for product recovery. Thus, this kind of chemical recycling imposes toxic and environmentally hazardous issues.

In the present review a comprehensive survey of PETrecycling methods is given, reviewing both conventional and exceptional methods (carbonization of PET, use of castor oil or ionic liquids for PET de-polymerization). This review focuses on chemical recycling methods with respect to the yields of the obtained reaction products and their usability for value added applications.

\section{Classification of recycling poly(ethylene terephthalate)}

\subsection{Energetic recycling}

\subsubsection{Pyrolysis}

Pyrolysis of PET-waste was first described in 1982 by Day et al. [96]. It is an alternative to PET disposal in landfills. In general, PET waste is pyrolysed without further purification of the plastic waste. Pyrolysis is carried out at temperatures between 200 and $900^{\circ} \mathrm{C}$ for 0.5 hours to 1 hour $[16-19,21,24-31,97-$ 101]. The majority of pyrolyses were conducted to produce aliphatic and aromatic hydrocarbons as an alternative for fossil fuels or as a source for chemicals $[17,19,21,24-31]$. Other research on pyrolysis was done to either model degradation kinetics or to use PET-wastes in the production of coke for steel making process [98, 100-103]. Finally, Urbanova et al. [104] studied the influence of IR laser irradiation for PET pyrolysis. As in conventional pyrolysis, they obtained aliphatic and aromatic hydrocarbons.

\subsubsection{Carbonization}

Carbonization is a second method of pyrolysing PET-waste. It is carried out at temperatures between $350-1550^{\circ} \mathrm{C}$ for 0.5 to 18.5 hours [105-111]. The major application of carbonization is the production of active carbon as adsorbent materials for either waste water or as $\mathrm{CO}_{2}$-scavenger $[105,108,110$, 111]. Carbonized PET-waste is also used as slag foaming agent and as a substitute of coal in steel making process $[106,107]$.

\subsection{Sorting}

Since PET-waste is often supplied in mixtures with other polymers, PET has to be separated from these polymers prior to re-processing. Therefore, several methods have been developed and are described in the literature. These methods comprise froth flotation, wet shaking table, swelling or thermo-mechanical procedures [112-123].

\subsubsection{Application of PET as additive}

A further use of recycled PET-waste after sorting is its use as additive in stone mastic asphalt, cementitious materials, mortars or concrete composites. The PET-waste is mixed in crushed shape in the corresponding materials to improve mechanical properties of these composites. Moreover, this method is in- 
tended to reduce the weight of such composites, when being used as material for the construction of large buildings [32-64]. A second possibility of using PET-waste as an additive is described by de Mello et al. [65], who applied PET particles as reinforcing component in polyurethane foams to improve the mechanical strength of the material. Finally, Zou et al. [124] studied the use of recycled PET as additive for paper coatings. Although proposing an eco-friendly alternative to energetic recycling methods and landfilling disposal, this method remains a downcycling application for PET-waste in the wider sense since the potential of the material PET is not used to its full extent in this low value application.

\subsection{Thermo-mechanical recycling}

\subsubsection{Re-melting without additives}

The simplest way of thermo-mechanical recycling is re-melting the sorted PET-waste. This method is applied in bottle-to-bottle technologies, where sorted PET-bottles are re-melted in crushed shape and reprocessed to bottles as beverage packaging. Several studies have been conducted on thermal re-processing PET. During this process, the polymer is exposed to high temperatures, shear forces and pressures. Thus, thermal degradation of PET occurs. As a consequence, reduced thermal and mechanical properties of the re-processed material were the main findings of these investigations (downcycling) [66-78]. Hence, a repeated thermal re-processing of PETwaste finally leads to a downcycling of the material.

\subsubsection{Re-melting with additives}

To make re-utilization of recycled PET feasible, the application of additives to PET-waste has emerged. Since the collection of PET-waste entails generally a mixture of differently colored PET-materials, such thermally re-processed material leads to undesired coloration of recycled PET. Therefore, the addition of complementary colors to PET-waste has been applied to mask discoloration [79]. Although being an approved procedure, this method probably limits the use of the recycled PET. Likewise, additives were developed to improve viscosity and impact strength of recycled PET, but the recyclate was excluded from food packaging in Europe [80].

Besides such additives, the addition of other polymers (e. g. polyethylene, polypropylene) or inorganic materials (clay minerals) has been applied for thermomechanical PET recycling to improve mechanical properties of the recyclate [81-94]. In addition to blending PET with a second polymer, the use of compatibilizers such as ethylene vinyl acetate, ethylenebutyl acrylate-glycidyl methacrylate copolymer, poly (styrene-ethylene/butylene-styrene) and epoxy-chain extenders has been applied to further improve mechanical properties [82-86]. Although the use of additives to PET can improve properties of thermo-mechanically recycled PET, it ultimately leads to a downcycling of the material, since this material becomes increasingly difficult to be recycled again due to the heterogeneous and inherent composition of PET with the other components.

\subsection{Chemical recycling \\ 2.4.1. Ionic liquids}

The application of ionic liquids for de-polymerization was first described in the year 2000 by Adams et al. [125]. This method was developed to avoid the drawbacks of former methods like methanolysis (high pressure and temperature), glycolysis (heterogeneous reaction products) or acidic and alkaline hydrolysis (pollution problems) to provide an ecofriendly degrading agent for polymers and to enable degradation under moderate reaction conditions. However, no application of the obtained reaction products was described. The general reaction scheme is depicted in Figure 1a [126].

Wang et al. [126] depolymerized PET with an excess of the ionic liquid at $120-200^{\circ} \mathrm{C}$ for $6-10$ hours. After the reaction was finished, the residual PET was removed, the degradation product precipitated by the addition of water and steam extracted for purification. They used different ionic liquids such as 1-butyl-3-methylimidazolium tetrachloroaluminate ([bmim $]^{+} \mathrm{AlCl}_{4}^{-}$), 1-butyl-3-methylimidazolium chloride $\left([\mathrm{bmim}]^{+} \mathrm{Cl}^{-}\right)$, 1-butyl-3-methylimidazolium bromide $\left([\mathrm{bmim}]^{+} \mathrm{Br}^{-}\right)$, 1-ethyl-3-methylimidazolium bromide ([emim $\left.]^{+} \mathrm{Br}^{-}\right)$, 1-butyl-3-methylimidazolium tetrafluoroborate ([bmim $\left.]^{+} \mathrm{BF}_{4}^{-}\right), 1$-butyl-3-methylimidazolium hexafluorophoasphate $\left([\mathrm{bmim}]^{+} \mathrm{PF}_{6}{ }^{-}\right)$, 1-butyl-3-methylimidazolium trifluoroacetate ([bmim $]^{+} \mathrm{CF}_{3} \mathrm{COO}^{-}$), 1-butyl-3-methylimidazolium acetate $\left([\mathrm{bmim}]^{+} \mathrm{CH}_{3} \mathrm{COO}^{-}\right)$(Figure $\left.1 \mathrm{~b}\right)$. Since the ionic liquid $[\mathrm{bmim}]^{+} \mathrm{Cl}^{-}$was most stable and PET was less soluble in the other liquids, only the reaction with $[\mathrm{bmim}]^{+} \mathrm{Cl}^{-}$was studied. Further, they studied the use of zinc acetate, tetrabutyl titanate and solid superacid as catalysts on the solubility of PET in the ionic liquid, but found that solubility was decreased 

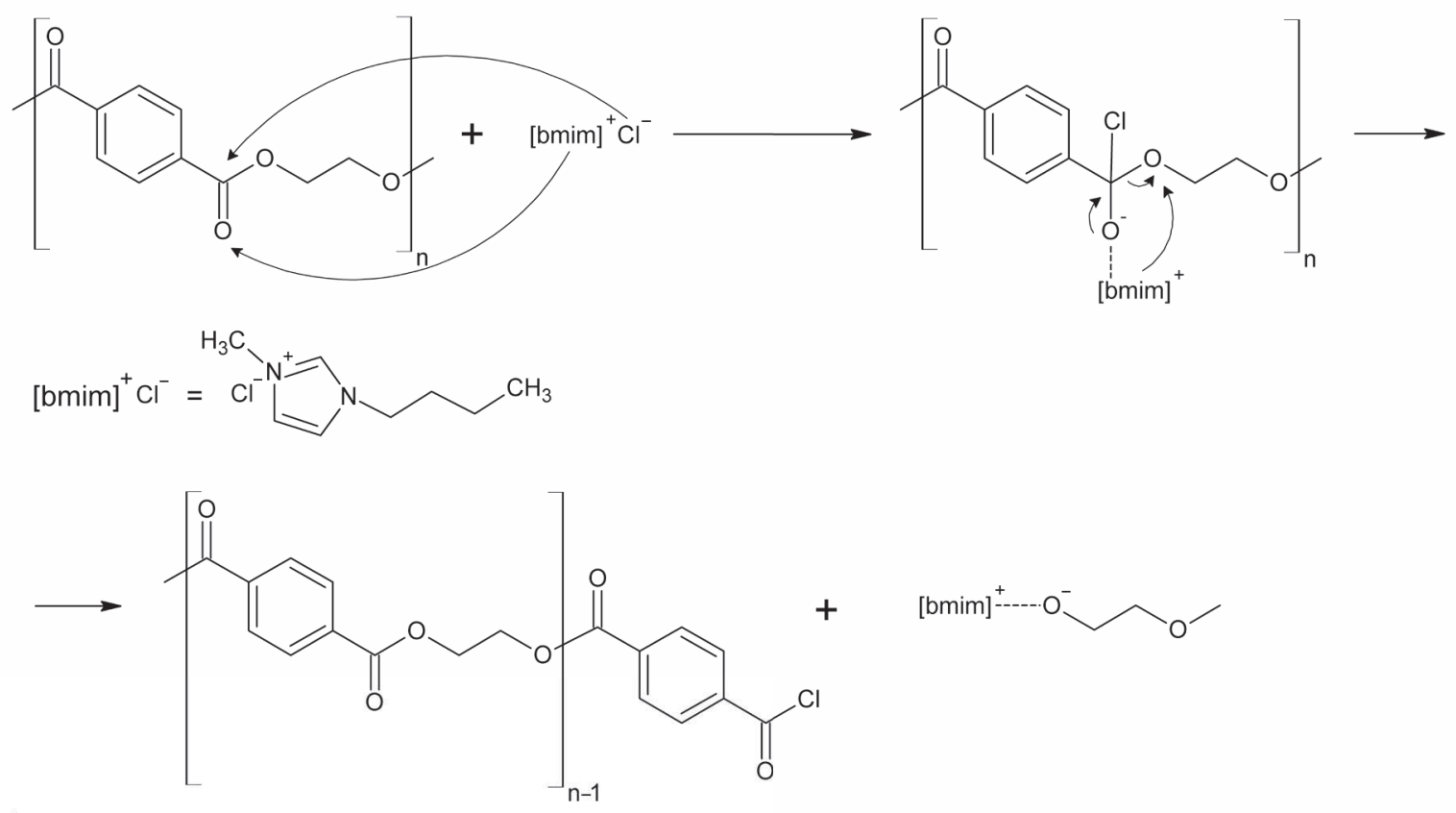

a)
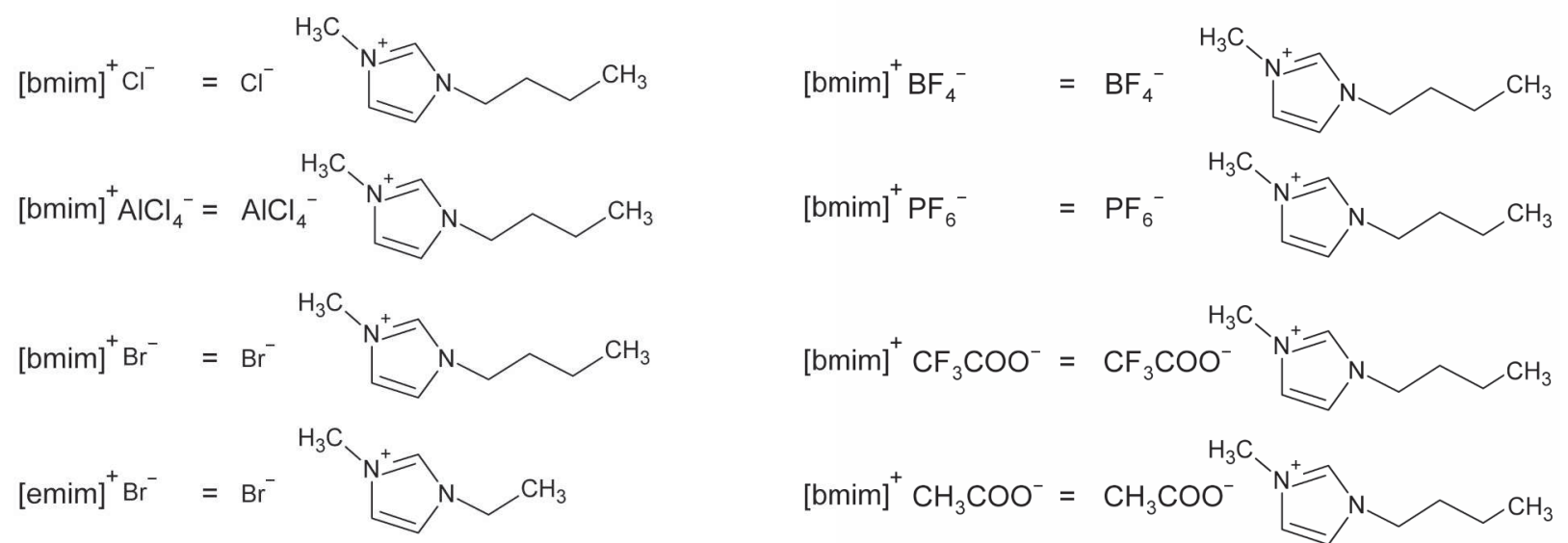$$
[\mathrm{bmim}]^{+} \mathrm{CF}_{3} \mathrm{COO}^{-}=\mathrm{CF}_{3} \mathrm{COO}^{-}
$$$$
[\mathrm{bmim}]^{+} \mathrm{CH}_{3} \mathrm{COO}^{-}=\mathrm{CH}_{3} \mathrm{COO}^{-}
$$

b)

Figure 1. Reaction of the ionic liquid 1-butyl-3-methylimidazolium chloride ([bmim $\left.]^{+} \mathrm{Cl}^{-}\right)$with PET (a), Applied ionic liquids (b) [126]

independent of the applied catalyst. As expected, they found an increased degradation rate with increasing reaction temperature. The molecular weight (characterized by GPC) of the undefined oligomers was in the range of 777 to $790 \mathrm{~g} \cdot \mathrm{mol}^{-1}$. The yield of these products was not determined. The main objectives of their research were the study of the reaction kinetics and the recyclability of the ionic liquids for the de-polymerization reaction of PET in terms of an eco-friendly degrading agent as mentioned above.

\subsubsection{Castor oil}

The application of castor oil for de-polymerization was first described in the year 1999 by Kržan [127]. This method was developed to provide a renewable substitute of petrochemical agents (for example, glycols) for PET de-polymerization. After de-polymerization, the reaction products were aimed for the preparation of polyurethane systems. The general reaction scheme is depicted in Figure 2 [128].

Beneš et al. [128] depolymerized PET with castor oil at $230-240^{\circ} \mathrm{C}$ for $0-2$ hours assisted microwaves. After the reaction was finished, solid residues were removed by vacuum filtration. Further, they applied zinc acetate, sodium carbonate and sodium hydrogen carbonate as catalysts. They found that the optimum reaction temperature range is between 230 and $240^{\circ} \mathrm{C}$, whereas below $230^{\circ} \mathrm{C}$ almost no reaction was observed. In contrast, reaction temperatures above $240^{\circ} \mathrm{C}$ lead to undesired side reactions of the castor 

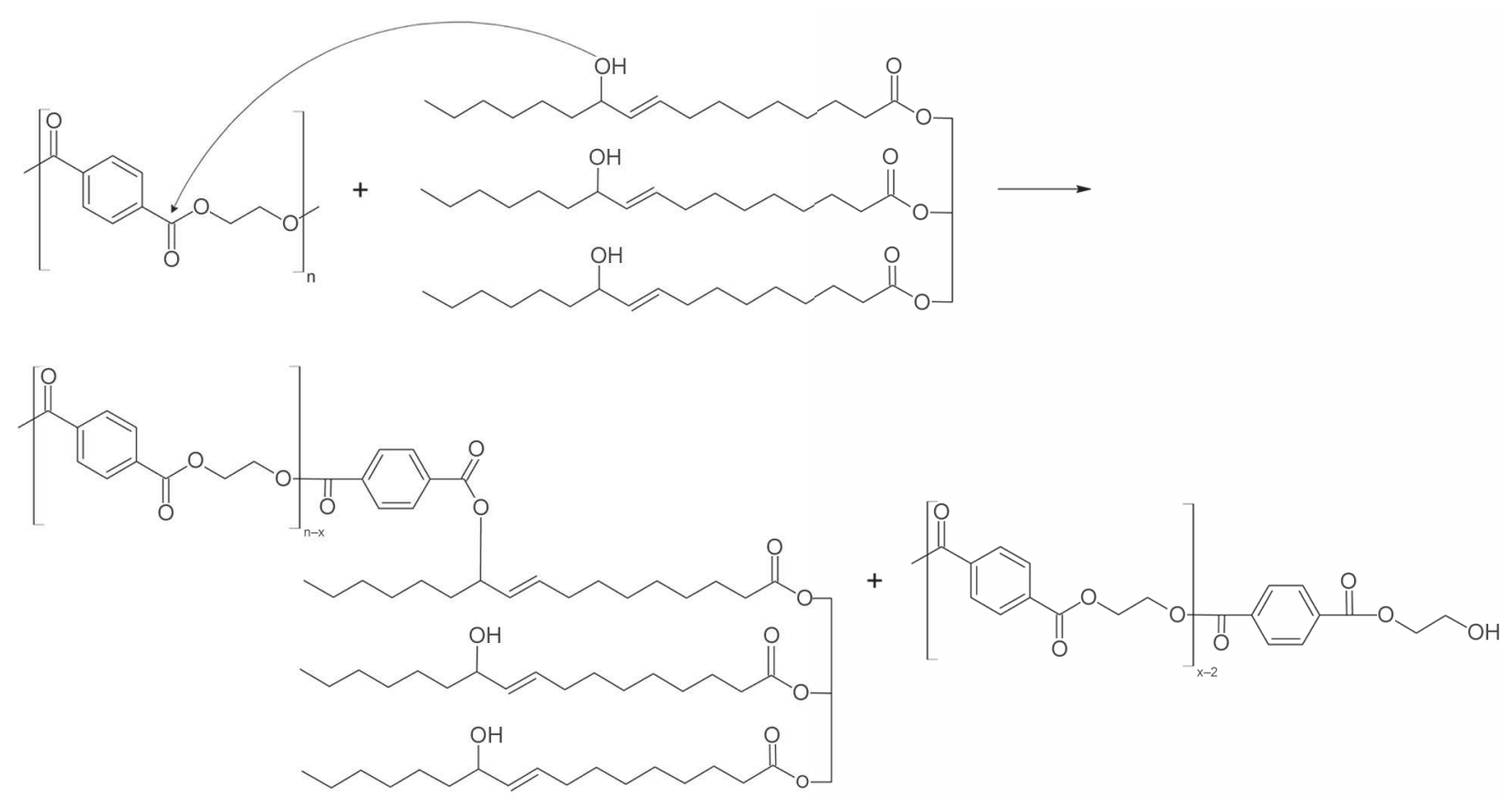

Figure 2. Reaction of castor oil with PET [128]

oil (dehydration, hydrolysis and transesterification). Moreover, zinc acetate seemed to be an efficient catalyst compared to sodium carbonate or sodium hydrogen carbonate. However, it was difficult to determine characteristic molecular weights (characterized by GPC) due to the excessive amount of applied castor oil, but it was stated, that no higher molecular weight PET-oligomers were obtained. Even with precise control of the reaction temperature a heterogeneous mixture of reaction products were obtained.

\subsubsection{De-polymerization of PET using enzymes}

The degradation of polymers using enzymes was first described in the year 1977 by Tokiwa and Suzuki [129]. As the use of ionic liquids and castor oil, this bio-chemical method was developed to provide an eco-friendly procedure of polymer recycling in contrast to conventional chemical recycling methods like methanolysis (high pressure and temperature), glycolysis (heterogeneous reaction products) or acidic and alkaline hydrolysis (pollution problems). The aimed application of reaction products after de-polymerization is the surface functionalization of polyester materials. Generally, PET was incubated in the enzymatic solution at temperatures between 30 to $60{ }^{\circ} \mathrm{C}$ for a period of time ranging from 3 to 14 days. Residual PET and solution were separated for product characterization [130-133].

As shown in Table 1, different enzymes such as saccharomonospora viridis cutinase polyesterase, ther- mobifidia fusca hydrolase, cutinase and lipase were applied for PET degradation. Mueller discussed the general applicability of thermobifidia fusca hydrolase for PET de-polymerization without mentioning a main degradation product or its yield [131].

Donelli et al. [132] only studied the surface morphology of PET treated with cutinase and did not make a qualitative or quantitative statement of possible reaction products. In contrast, Zhang et al. [133] studied the application of lipase as degrading agent for diethylene glycol terephthalate (DGTP) and PET at $30^{\circ} \mathrm{C}$ and 14 days. They found that lipase is capable of fully converting DGTP to terephthalic acid (TPA), whereas the degradation of PET to TPA was negligible.

Finally, Kawai et al. [130] used saccharomonospora viridis cutinase polyesterase for degradation of PET at reaction conditions of $63^{\circ} \mathrm{C}$ and 3 days. With this enzyme it was possible to obtain $10-27 \%$ of TPA form PET degradation.

In these references, the authors conclude, that depolymerization of PET using enzymes is generally possible as an eco-friendly alternative to conventional chemical recycling methods, since the latter require high pressure and temperature equipment and considerable amounts of toxic as well as hazardous chemicals. However, efficiency is rather low with respect to complete de-polymerization of PET and hence quantitative recovery of homogeneous reaction products for re-use is not possible. 
Table 1. Reaction conditions and yields of enzymatic degradation of PET

\begin{tabular}{|l|c|l|c|c|c|}
\hline \multicolumn{1}{|c|}{ Reaction product } & $\begin{array}{c}\text { Yield } \\
{[\%]}\end{array}$ & Enzyme & $\begin{array}{c}\text { Reaction } \\
\text { temperature } \\
{\left[{ }^{\circ} \mathbf{C}\right]}\end{array}$ & $\begin{array}{c}\text { Reaction time } \\
{[\text { days] }}\end{array}$ & Reference \\
\hline Monomer, TPA $^{\text {a }}$ & 10 to 27 & Saccharomonospora viridis cutinase polyesterase & 63 & 3 & {$[130]$} \\
\hline Monomer, TPA & & 30 & 14 & {$[133]$} \\
\hline Not given & negligible & Lipase & 55 & not given & {$[131]$} \\
\hline Not given & not given & Thermobifidia fusca hydrolase & 40 & 0.1 & {$[132]$} \\
\hline
\end{tabular}

${ }^{\text {aTPA: Terephthalic acid }}$

\subsubsection{Alcoholysis}

Alcoholysis for de-polymerization of PET was first described in the year 1991 by Wang et al. [134]. This method was developed to avoid the drawbacks of the methods like glycolysis (heterogeneous reaction products) or acidic and alkaline hydrolysis (pollution problems) to provide a renewable and eco-friendly degrading agent for polymers [135]. The general reaction scheme is depicted in Figure 3a.

Generally, PET is de-polymerized with an excess of an alcohol to yield corresponding esters of terephthalic acid and ethylene glycol [136].

Fávaro et al. [135] completely de-polymerized PET with excess supercritical ethanol at $255^{\circ} \mathrm{C}$ and 116 bar for 30 to 120 minutes. They obtained diethylene terephthalate with $80 \%$ yield (Table 2 ) as monomer for PET synthesis. However, the obtained ethylene glycol was only suitable for an impaired application as cooling liquid due to its reduced purity. Mendes et al. [34] used pentaerythrytol (PENTE) for alcoholysis of PET at $250^{\circ} \mathrm{C}$ for 10 minutes. They melt-mixed PET with different concentrations of PENTE and found with increasing amount of PENTE the trend of formation from branched, undefined low molecular weight oligomers to the monomer bis(trihydroxy neopentyl) terephthalate (BTHNPT). This monomer could be used as additive for asphalt or as adhesives.

Nikje and Nazari studied alcoholysis of PET using 1-butanol, 1-pentanol and 1-hexanol. They refluxed PET with excess alcohol under microwave irradiation to accelerate complete de-polymerization of PET and obtained terephthalic acid with high purity in yields between 84 and 96\% [137]. The use of microwave irradiation provided short reaction times and no further oxidation of the side product ethylene glycol. In this case, the aimed application of reaction products after de-polymerization was the synthesis of virgin PET.

Likewise, Liu et al. [136] used excess 1-butanol for alcoholysis of PET and studied the influence of different catalysts and their re-useability on PET conversion, but did not mention any aimed application of obtained reaction products after de-polymerization. Reaction was carried out at $205^{\circ} \mathrm{C}$ for $480 \mathrm{~min}$ utes to give the monomer dibutyl terephthalate (DBTP). Highest yield of 95\% was obtained using (3-sulfonic acid)-propyltriethylammonium chlorozincinate as catalyst.

In contrast to the previous alcoholytic methods, Dutt and Soni applied excess 2-ethyl-1-hexanol for PETalcoholysis to produce plasticizers for nitrile rubber<smiles>[R]OC(=O)c1ccc(C(=O)O[R])cc1</smiles>

b)

Figure 3. Chemical recycling methods of PET ((a) Alcoholysis, (b) Methanolysis) 
Table 2. Reaction conditions and yields of alcoholysis, methanolysis and hydrolysis of PET

\begin{tabular}{|c|c|c|c|c|c|c|c|}
\hline Reaction product & $\begin{array}{l}\text { Yield } \\
{[\%]}\end{array}$ & Reagent & $\begin{array}{c}\text { Reaction } \\
\text { temperature } \\
{\left[{ }^{\circ} \mathrm{C}\right]} \\
\end{array}$ & $\begin{array}{c}\text { Reaction } \\
\text { time } \\
\text { [min] }\end{array}$ & $\begin{array}{c}\text { Pressure } \\
\text { [bar] }\end{array}$ & Catalyst & Reference \\
\hline Monomer, DETP ${ }^{\mathrm{a}}$ & 80 & Ethanol & 255 & $30-120$ & 116 & none & [135] \\
\hline Monomer, TPA ${ }^{\mathrm{b}}$ & 84 & 1-Hexanol & 100 & not given & $1^{\mathrm{f}}$ & Potassium hydroxide & [137] \\
\hline Monomer, DBTP ${ }^{\mathrm{c}}$ & 95 & 1-Butanol & 205 & 480 & $1^{\mathrm{f}}$ & Acidic ionic liquids & [136] \\
\hline Monomer, TPA ${ }^{\mathrm{b}}$ & 96 & 1-Butanol & 100 & not given & $1^{\mathrm{f}}$ & Potassium hydroxide & [137] \\
\hline Monomer, TPA ${ }^{\mathrm{b}}$ & 96 & 1-Pentanol & 100 & not given & $1^{\mathrm{f}}$ & Potassium hydroxide & [137] \\
\hline Monomer, BTHNPT & not given & Pentaerythrytol & 250 & 10 & $1^{\mathrm{f}}$ & Zinc acetate & [34] \\
\hline $\begin{array}{l}\text { Oligomers, } \\
{\left[250-1430 \mathrm{~g} \cdot \mathrm{mol}^{-1}\right]}\end{array}$ & not given & $\begin{array}{l}\text { Titanium } \\
\text { alkoxide }\end{array}$ & $270-280$ & 1 to 20 & $1^{\mathrm{f}}$ & none & [139] \\
\hline $\begin{array}{l}\text { Oligomers, } \\
{\left[450-900 \mathrm{~g} \cdot \mathrm{mol}^{-1}\right]}\end{array}$ & not given & $\begin{array}{r}\text { 2-Ethyl-1- } \\
\text { Hexanol }\end{array}$ & $170-190$ & $600-720$ & $1^{\mathrm{f}}$ & none & [138] \\
\hline Monomer, DMTP & 60 & Methanol & 270 & $0-90$ & $1-150$ & none & [142] \\
\hline Monomer, DMTP ${ }^{\mathrm{e}}$ & 80 & Methanol & 300 & $0-90$ & 9.8 & none & [141] \\
\hline Monomer, DMTP ${ }^{\mathrm{e}}$ & 80 & Methanol & $300-350$ & $2-120$ & 200 & none & [144] \\
\hline Monomer, DMTP & 80 & Methanol & 300 & $2-120$ & 200 & none & [145] \\
\hline Monomer, DMTP ${ }^{\mathrm{e}}$ & 88 & Methanol & 200 & 120 & not given & Aluminium triisopropoxide & [146] \\
\hline Monomer, DMTP & 98 & Methanol & 300 & $0-90$ & 147 & none & [141] \\
\hline Monomer, DMTP ${ }^{\mathrm{e}}$ & 98 & Methanol & 330 & $0-90$ & $1-150$ & none & [142] \\
\hline Monomer, DMTP & $60-95$ & Methanol & $250-270$ & $0-60$ & $85-140$ & Zinc acetate & [148] \\
\hline Monomer, DMTP & not given & Methanol & $160-200$ & $0-60$ & 16 & Zinc acetate & [147] \\
\hline Monomer, $\mathrm{TPA}^{\mathrm{b}}$ & 85 & $\begin{array}{c}\mathrm{H}_{2} \mathrm{O}, \text { Sodium } \\
\text { Hydroxide }\end{array}$ & 99 & 150 & $1^{\mathrm{f}}$ & none & [166] \\
\hline Monomer, $\mathrm{TPA}^{\mathrm{b}}$ & 90 & $\mathrm{H}_{2} \mathrm{O}$ & $115-145$ & $0-420$ & $1^{\mathrm{f}}$ & {$\left[\left(\mathrm{CH}_{3}\right)_{3} \mathrm{~N}\left(\mathrm{C}_{16} \mathrm{H}_{33}\right)\right]_{3}\left[\mathrm{PW}_{12} \mathrm{O}_{40}\right]$} & {$[150]$} \\
\hline Monomer, $\mathrm{TPA}^{\mathrm{b}}$ & 90 & $\mathrm{H}_{2} \mathrm{O}$ & $250-420$ & $0-60$ & 480 & none & [154] \\
\hline Monomer, TPA ${ }^{\mathrm{b}}$ & 91 & $\mathrm{H}_{2} \mathrm{O}$ & $220-300$ & 6 to 60 & 32 & Zinc acetate & [152] \\
\hline Monomer, $\mathrm{TPA}^{\mathrm{b}}$ & 96 & $\mathrm{H}_{2} \mathrm{O}$ & 200 & $30-240$ & 16 & none & [153] \\
\hline Monomer, $\mathrm{TPA}^{\mathrm{b}}$ & 96 & $\begin{array}{l}\mathrm{H}_{2} \mathrm{O}, \text { Sodium } \\
\text { Hydroxide }\end{array}$ & Molten state ${ }^{\mathrm{g}}$ & 6 & $1^{\mathrm{f}}$ & none & [168] \\
\hline Monomer, $\mathrm{TPA}^{\mathrm{b}}$ & 98 & $\begin{array}{l}\mathrm{H}_{2} \mathrm{O}, \text { Sodium } \\
\text { Hydroxide }\end{array}$ & $120-150$ & $60-420$ & $1^{\mathrm{f}}$ & none & [163] \\
\hline Monomer, TPA ${ }^{\mathrm{b}}$ & 98 & $\begin{array}{c}\mathrm{H}_{2} \mathrm{O} \text {, Sodium } \\
\text { Hydroxide }\end{array}$ & $70-95$ & $300-360$ & $1^{\mathrm{f}}$ & Trioctyl ammonium bromide & {$[165]$} \\
\hline Monomer, $\mathrm{TPA}^{\mathrm{b}}$ & 99 & $\mathrm{H}_{2} \mathrm{O}$ & 205 & $6-240$ & 16 & none & [155] \\
\hline Monomer, $\mathrm{TPA}^{\mathrm{b}}$ & 99 & $\mathrm{H}_{2} \mathrm{O}$ & 190 & 10 & $1^{\mathrm{f}}$ & Hydrotalcite & {$[156]$} \\
\hline Monomer, TPA ${ }^{\mathrm{b}}$ & 99 & $\begin{array}{c}\mathrm{H}_{2} \mathrm{O} \text {, Sodium } \\
\text { Hydroxide }\end{array}$ & $90-98$ & $0-60$ & $1^{\mathrm{f}}$ & $\begin{array}{l}\text { Tetrabutyl ammonium } \\
\text { bromide }\end{array}$ & [164] \\
\hline Monomer, TPA ${ }^{\mathrm{b}}$ & 99 & $\begin{array}{l}\mathrm{H}_{2} \mathrm{O}, \text { Sodium } \\
\text { Hydroxide }\end{array}$ & 90 & $600-4200$ & $1^{\mathrm{f}}$ & Tetrabutyl ammonium iodide & [167] \\
\hline Monomer, $\mathrm{TPA}^{\mathrm{b}}$ & 100 & $\begin{array}{l}\mathrm{H}_{2} \mathrm{O}, \text { Sodium } \\
\text { Hydroxide }\end{array}$ & 180 & 30 & $1^{\mathrm{f}}$ & $\begin{array}{l}\text { Trioctylmethyl ammonium } \\
\text { bromide }\end{array}$ & [157] \\
\hline Monomer, $\mathrm{TPA}^{\mathrm{b}}$ & 100 & $\begin{array}{l}\mathrm{H}_{2} \mathrm{O} \text {, Sulfuric } \\
\text { Acid }\end{array}$ & 150 & $60-360$ & $1^{\mathrm{f}}$ & none & [161] \\
\hline Monomer, $\mathrm{TPA}^{\mathrm{b}}$ & not given & $\mathrm{H}_{2} \mathrm{O}$ & $100-250$ & 120 & Autogen & none & [158] \\
\hline Monomer, TPA ${ }^{b}$ & not given & $\mathrm{H}_{2} \mathrm{O}$, Nitric Acid & Reflux & not given & $1^{\mathrm{f}}$ & none & [160] \\
\hline Not given & not given & $\mathrm{H}_{2} \mathrm{O}$ & $140-180$ & not given & 10 & none & {$[151]$} \\
\hline Not given & not given & $\begin{array}{l}\mathrm{H}_{2} \mathrm{O} \text {, Sulfuric } \\
\text { Acid }\end{array}$ & 30 & $6-120$ & $1^{\mathrm{f}}$ & none & [159] \\
\hline Not given & not given & $\begin{array}{c}\mathrm{H}_{2} \mathrm{O}, \text { Sodium } \\
\text { Hydroxide }\end{array}$ & $\begin{array}{l}\text { Ambient } \\
\text { temperature }\end{array}$ & 15 & $1^{\mathrm{f}}$ & none & {$[162]$} \\
\hline Not given & not given & $\begin{array}{c}\mathrm{H}_{2} \mathrm{O}, \text { Sodium } \\
\text { Hydroxide }\end{array}$ & 120 & not given & $1^{\mathrm{f}}$ & none & [169] \\
\hline Not given & not given & $\begin{array}{c}\mathrm{H}_{2} \mathrm{O}, \text { Sodium } \\
\text { Hydroxide }\end{array}$ & $250^{\mathrm{h}}$ & not given & $1^{\mathrm{f}}$ & none & {$[170]$} \\
\hline $\begin{array}{l}\text { Oligomers, } \\
{\left[540 \mathrm{~g} \cdot \mathrm{mol}^{-1}\right]}\end{array}$ & 97 & $\mathrm{H}_{2} \mathrm{O}$ & 170 & 180 & $1^{\mathrm{f}}$ & Zinc acetate & [149] \\
\hline $\begin{array}{l}\text { Oligomers, } \\
{\left[2047 \mathrm{~g} \cdot \mathrm{mol}^{-1}\right]}\end{array}$ & 99 & $\mathrm{H}_{2} \mathrm{O}$ & 170 & 180 & $1^{\mathrm{f}}$ & Potassium hydroxide & [149] \\
\hline
\end{tabular}

${ }^{\mathrm{a} D E T P:}$ Diethyl terephthalate. ${ }^{\mathrm{b}} \mathrm{TPA}$ : Terephthalic acid. ${ }^{\mathrm{c} D B T P}$ : Dibutyl terephthalate. ${ }^{\mathrm{d}}$ BTHNPT: Bis(tri-hydroxy neopentyl) terephthalate. ${ }^{\mathrm{D} D M T P}$ : Dimethyl terephthalate. ${ }^{\mathrm{f}}$ No pressure was given in the experimental section, thus, atmospheric pressure was assumed. ${ }^{g}$ Reaction was carried out in a microwave reactor and reaction mixture was heated until the mixture was completely molten. ${ }^{\mathrm{h}}$ Temperature during a differential scanning calorimetry measurement. 
and nitrile rubber polyvinyl chloride (PVC) blends. The reaction was carried out at $170-190^{\circ} \mathrm{C}$ for 10 12 hours. Complete alcoholysis of PET was reached after 12 hours [138]. However, the composition of the obtained reaction mixture with respect to monomers or oligomers is not clarified. Although a molecular structure of low molecular weight oligomers (450 $\left.900 \mathrm{~g} \cdot \mathrm{mol}^{-1}\right)$ is postulated, it is not clear whether and how many monomers were obtained, since reaction was complete after 12 hours.

Chabert et al. [139] used titanium tetra-n-butoxide and titanium tetra-n-propoxide for PET de-polymerization. Concentration of titanium tetra-n-butoxide and titanium tetra-n-propoxide were 22 and $50 \%$ in the PET-mixture, which was extruded at $270-280^{\circ} \mathrm{C}$. They found that chain scission of PET proceeded faster using titanium tetra-n-propoxide compared to titanium tetra-n-butoxide. They further studied the number of active alkoxide-groups in corresponding titanium tetra-n-alkoxides and found that mainly two alkoxide-groups of the titanium tetra-n-alkoxide were involved in the chain scission reaction of PET. Mixtures of undefined low molecular weight oligomers in the range between 250 and $1430 \mathrm{~g} \cdot \mathrm{mol}^{-1}$ were obtained. However, they did not mention any aimed application of reaction products after de-polymerization. This procedure is advantageous in contrast to prior described solvent based procedures, which required additional separation and purification steps. However, functionality of PET-oligomers was limited due to alkyl end-groups.

Among the alcoholysis methods, reaction with methanol has gained special importance because of the low price and the availability of methanol. Methanolysis for de-polymerization of PET was first described in the year 1962 by Heisenberg et al. [140]. The application of the reaction products after depolymerization was to provide the monomers for synthesis of virgin PET. The general reaction scheme is depicted in Figure $3 b$.

Generally, PET is de-polymerized with an excess of methanol at $160-350^{\circ} \mathrm{C}$ (Table 2) to yield the monomer dimethyl terephthalate (DMTP). To increase the yield of DMTP and to shorten reaction times high pressures (9-200 bar, Table 2) are applied [141-148].

Genta and coworkers [141, 142] studied the effect of supercritical methanol compared to vapor methanol for PET de-polymerization. They found that de-polymerization proceeds faster in supercritical methanol than in vapor methanol. The reaction product consist- ed of a mixture of bis(hydroxy-ethylene) terephthalate (BHET), methyl-2-hydroxy ethylene terephthalate (MHET) and dimethyl terephthalate (DMTP). The yield of the main product DMTP was around $80 \%$. Furthermore, the energy consumption of the supercritical methanolysis $\left(2.35 \cdot 10^{6} \mathrm{~kJ} \cdot \mathrm{kmol}^{-1}\right)$ was lower than of the vapor methanolysis $\left(2.84 \cdot 10^{6} \mathrm{~kJ} \cdot \mathrm{kmol}^{-1}\right)$. Goto reviewed the general applicability of supercritical fluids for de-polymerization, including methanol. Although supercritical methanol was suitable for PET de-polymerization and yielded DMTP as the main reaction product (yield $80 \%$ ), the reaction mixture also consisted of BHET and MHET and hence entailed further purification steps [143].

Goto and coworkers [144, 145] studied the reaction kinetics during supercritical methanolysis of PET. Reaction was carried out at $300-350^{\circ} \mathrm{C}$ at 200 bar (Table 2). Beside terephthalic acid monomethyl ester (TAMME), MHET and BHET, they obtained DMTP as main product in yields of $80 \%$.

Likewise, Yang et al. [148] studied the effect of reaction temperature and time during supercritical methanolysis of PET (Table 2). Excess methanol was used for PET de-polymerization. They found that the extent of the reaction increased with increasing temperature and time. The reaction product consisted of DMTP, MHET, BHET and their dimers, which entailed further purification steps of the monomer DMTP. The yield of DMTP ranged from $60-95 \%$.

Kurokawa et al. [146] studied the effect of aluminium tri-isopropoxide (ATIP) as catalyst and the solvent mixture of methanol and toluene on methanolysis of PET. Reaction was carried out at $200^{\circ} \mathrm{C}$ without high pressure conditions (Table 2). With the application of the catalyst ATIP, the yield of the main product DMTP was raised to $67 \%$. Finally, the application of ATIP combined with the solvent mixture methanol and toluene, the yield of DMTP was maximized to $88 \%$.

Beside the use of supercritical methanol or additional application of a catalyst for methanolysis, Siddiqui et al. [147] studied the influence of microwave assisted methanolysis of PET in the temperature range from 160 to $200^{\circ} \mathrm{C}$ with the addition of zinc acetate as catalyst. They found that the amount of de-polymerized PET increased with increasing temperature and increasing microwave power from 50 to $200 \mathrm{~W}$. The characterized main product was DMTP, which was not quantified by the authors. 


\subsubsection{Hydrolysis}

Hydrolysis of PET can be classified into neutral, acidic and alkaline hydrolysis (Table 2). The general reaction scheme of neutral and acidic hydrolysis is depicted in Figure 4. Generally, the main application of obtained reaction products after de-polymerization was to provide monomers for the synthesis of virgin PET. Neutral hydrolysis of PET is generally conducted with excess water at high temperature ranges between $115-420^{\circ} \mathrm{C}$ and high pressure ranges from 10 to 480 bar. Correspondingly, reaction times are up to 7 hours [149-158].

Güçlü et al. [149] found that the solvent xylene provided greater de-polymerization of PET, whereas the catalysts zinc acetate or potassium hydroxide had negligible effect. They obtained low molecular weight oligomers $\left(540+2047 \mathrm{~g} \cdot \mathrm{mol}^{-1}\right.$, Table 2$)$ with yields of $97+99 \%$.

Other studies investigated the effects of different reaction parameters on neutral hydrolysis of PET, such as catalysts (zinc acetate, potassium hydroxide, phase transfer catalyst, hydrotalcite) $[151,153,156]$, steam or plasma treatment $[154,155]$ and microwave irradiation [157]. Although having different foci in these papers, the monomer TPA was obtained as reaction product in yields of $90-100 \%$ (Table 2).

In contrast to neutral hydrolysis, acidic hydrolysis of PET is generally conducted with excess acid (sulfuric or nitric acid) at ambient temperature and atmospheric pressure. Reaction times are in between 6 and 360 minutes $[159,160]$. Yoshioka et al. [161] conducted acidic hydrolysis at $150^{\circ} \mathrm{C}$. de Carvalho et al. [159] completely de-polymerized PET to yield TPA. Kumar and Rajeswara Rao studied kinetics of acidic hydrolysis and Kumar and Rao [160] and Yoshioka et al. [161] examined the re-usability of dilute sulfuric acid for the de-polymerization of PET. In both stud- ies, TPA was obtained. Although neutral and acidic hydrolysis of PET gave high yields of the monomer TPA, purification of the reaction product is solvent consuming, and hence imposes environmental issues. For the alkaline hydrolysis of PET-waste metal hydroxides are used. This method yields the corresponding metal salts of terephthalic acid. By a subsequent acidification of the formed salt, pure terephthalic acid is obtained. Alkaline hydrolysis of PET-waste is generally conducted with excess metal hydroxide (sodium or potassium hydroxide) at temperature ranges between $70-150^{\circ} \mathrm{C}$. Reaction times are between 6 minutes and 70 hours (Table 2). The general reaction scheme of alkaline hydrolysis is depicted in Figure 4 [162-171].

Caparanga et al. [162] used alkaline washing as pretreatment of PET-waste before actual recycling. Karayannidis et al. [163] completely de-polymerized PET to obtain pure TPA in yields of $98 \%$.

Kosmidis et al. [165], Mishra et al. [166], Karayannidis et al. [170] studied degradation kinetics of alkaline hydrolyis of PET. Kosmidis et al. [165] used a catalyst (trioctyl ammonium bromide) and obtained a TPA yield of 98\%, whereas Mishra et al. [166] did not use a catalyst and obtained a TPA yield of $85 \%$. Karayannidis et al. [170] did not determine any yield of any reaction product in alkaline PET hydrolysis.

Additionally to conventional alkaline hydrolysis, Khalaf and Hasan [164], Paliwal and Mungray [167], Shafique et al. [168] additionally used microwave or ultrasound irradiation for de-polymerization of PET. Although Khalaf and Hasan as well as Paliwal and Mungray used a catalyst (tetra butyl ammonium bromide, tetra butyl ammonium iodide), their TPA yield of $99 \%$ was not significantly greater than the yield of Shafique et al. [168] with 96\%.
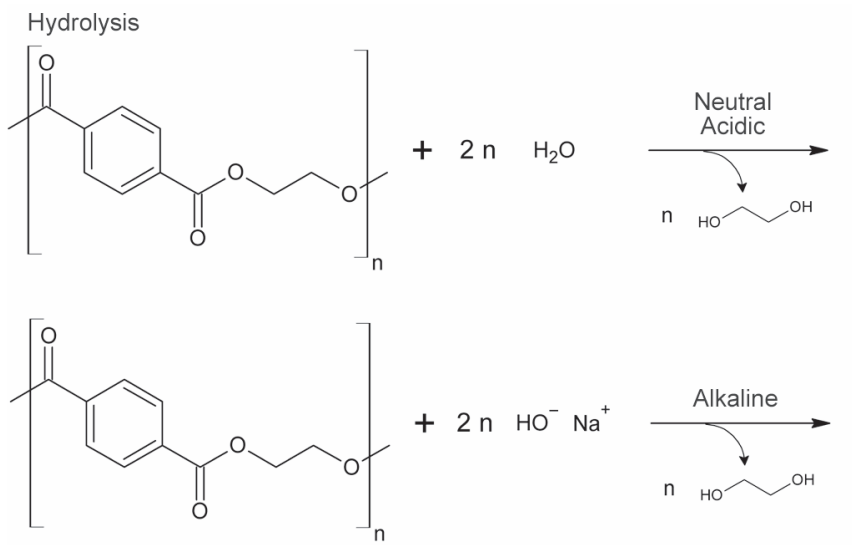<smiles>O=C(O)c1ccc(C(=O)O)cc1</smiles>
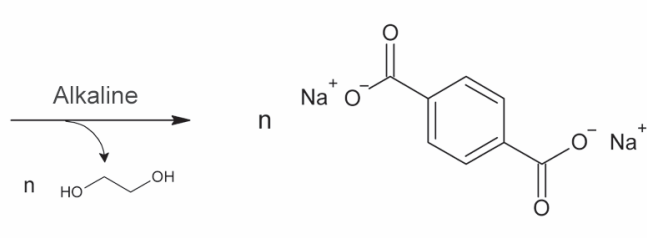

Figure 4. Chemical recycling methods of PET (Neutral, acidic and alkaline Hydrolysis) 
Finally, Rosmaninho et al. [169] used alkaline hydrolysis for surface modification of PET not to yield PET monomers but to synthesize a cation exchange material as adsorbent for cationic contaminants. They compared this procedure with an acid surface modified PET. They found that acid modification generates more efficiently carboxyl-groups as potential cation exchange positions.

In most cases of the above described procedures, reaction products needed to be separated and purified after complete reaction.

\subsubsection{Glycolysis}

The general reaction scheme of PET glycolysis is depicted in Figure 5. Glycolysis of PET leads to the formation of PET-monomers and low molecular weight PET-oligomers (Table 3). Thus, a main application of the reaction products after de-polymerization was to provide monomers for the synthesis of virgin PET. The main process parameters of glycolysis are reaction temperature $\left(110-270{ }^{\circ} \mathrm{C}\right)$ and reaction time (up to 15 hours) [99, 172-199]. In contrast to methanolysis, there is only little use of high pressure for glycolysis of PET [10, 180, 200].

Generally, the degrading agent was used in excess for de-polymerization of PET. Predominantly, ethylene glycol was used as degrading agent to give mainly the PET-monomer bis(hydroxy-ethylene) terephthalate (BHET) in yields between 46 to $100 \%$ [10, 11, 99, 184, 185, 187-189, 191-193, 195, 198, 200, 201-214]. Saint-Loup and co-workers also used ethylene glycol in reactive extrusion to produce low molecular weight oligomers $\left(1450+1800 \mathrm{~g} \cdot \mathrm{mol}^{-1}\right)$ without quantification of their yields for synthesis of PET-polycarbonate polyesters. However, these oligomers had to be separated and purified for further processing, since the crude reaction product consisted of a heterogeneous mixture of BHET-analoga [215218].

The second most common degrading agent for glycolysis was diethylene glycol. Here, both BHET and low molecular weight oligomers (dimers to hexam- ers of BHET) were obtained, but no quantification of the yield was made $[64,173,174,177-179,190$, 181, 219, 220].

Further, but less applied chemicals for PET-glycolysis were propylene glycol, diethanol amine and triethanol amine. Using propylene glycol, BHET-analogues were obtained, but not quantified, since these intermediates were directly used for synthesis of unsaturated polyester resins [186, 190, 221]. Application of diethanol amine and triethanol amine yielded low molecular weight oligomers $\left(900+1130 \mathrm{~g} \cdot \mathrm{mol}^{-1}\right.$, not quantified) for the use as dispersants or synthesis of epoxy resin. Again, additional separation and purification of the reaction products were necessary [176, 196, 197].

The least applied diols were BHET, neopentyl glycol (NPG), tetraethylene glycol (TEEG), poly(ethylene glycol) $\left(400 \mathrm{~g} \cdot \mathrm{mol}^{-1}\right)$, poly(tetramethylene oxide) $\left(650 \mathrm{~g} \cdot \mathrm{mol}^{-1}\right)$ and terpoly[poly(oxyethylene)-poly(oxypropylene)-poly(oxyethylene)] $\left(1100 \mathrm{~g} \cdot \mathrm{mol}^{-1}\right)$. In case of NPG, the corresponding monomer bis(neopentyl ethylene) terephthalate was obtained in a yield of $70 \%$. With the other diols low molecular weight oligomers were obtained, since de-polymerization agents were already of low molecular weight. These reaction products were used for the synthesis of copolymers containing polyester species. Additionally, a consecutive separation and purification of the obtained products was necessary $[175,182,194]$.

Another parameter for PET-glycolysis is the application of a catalyst. A various number has been used for PET-glycolysis and is listed in Table 3. The most important catalysts were zinc acetate and manganese acetate $[64,173-175,182-186,192,193,200,202-$ 204, 206, 208, 210, 211, 213, 219]. Further catalysts, but less used metal acetate catalysts, than the aforementioned ones, are cobalt and lead acetate [192, 205, 211]. Baliga and Wong studied the influence of the cation zinc, manganese, cobalt and lead on the catalytic effect of corresponding metal acetates on PET-glycolysis. They found that de-polymerization increased in the order $\mathrm{Pb}^{2+}<\mathrm{Co}^{2+}<\mathrm{Mn}^{2+}<\mathrm{Zn}^{2+}$.

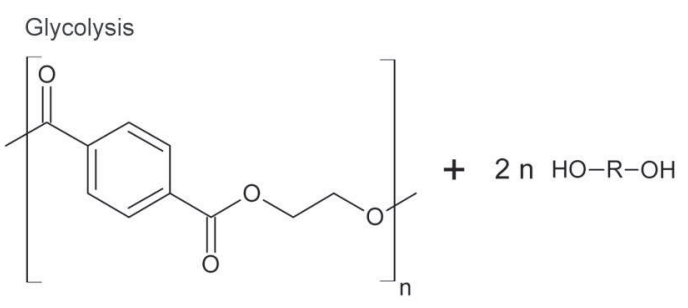

Figure 5. Chemical recycling methods of PET (Glycolysis) 
Table 3. Reaction conditions and yields of PET glycolysis

\begin{tabular}{|c|c|c|c|c|c|c|c|}
\hline $\begin{array}{c}\text { Reaction } \\
\text { product }\end{array}$ & $\begin{array}{l}\text { Yield } \\
{[\%]}\end{array}$ & Reagent & $\begin{array}{c}\text { Reaction temperature } \\
{\left[{ }^{\circ} \mathrm{C}\right]}\end{array}$ & $\begin{array}{l}\text { Reaction time } \\
\text { [hours] }\end{array}$ & $\begin{array}{c}\text { Pressure } \\
\text { [bar] }\end{array}$ & Catalyst & Reference \\
\hline Monomers & 0.3 & $\mathrm{EG}^{\mathrm{a}}$ & 300 & $0.4-0.8$ & 11 & none & [10] \\
\hline Monomers & 2.5 & $\mathrm{EG}^{\mathrm{a}}$ & 350 & $0.4-0.8$ & 25 & none & [10] \\
\hline Monomers & 25 & $\mathrm{EG}^{\mathrm{a}}$ & $80-200$ & 15 & $1^{\mathrm{q}}$ & $\mathrm{ZnSO}_{4}$ & [192] \\
\hline Monomers & 46 & $\mathrm{EG}^{\mathrm{a}}$ & $150-190$ & 1 to 4 & $1^{\mathrm{q}}$ & $\mathrm{Cu}(\mathrm{OAc})_{2}-[\mathrm{Bmim}][\mathrm{OAc}]^{\mathrm{r}}$ & [194] \\
\hline Monomers & 54 & $\mathrm{EG}^{\mathrm{a}}$ & $150-190$ & 1 to 4 & $1^{\mathrm{q}}$ & $\mathrm{Zn}(\mathrm{OAc})_{2}-[\mathrm{Bmim}][\mathrm{OAc}]^{\mathrm{s}}$ & [194] \\
\hline Monomers & 57 & $\mathrm{EG}^{\mathrm{a}}$ & 196 & 9 & $1^{q}$ & $\mathrm{FeCl}_{2}$ & [190] \\
\hline Monomers & 60 & $\mathrm{EG}^{\mathrm{a}}$ & 196 & 8 & $1^{\mathrm{q}}$ & $\mathrm{Na}_{2} \mathrm{SO}_{4}$ & [186] \\
\hline Monomers & 60 & $\mathrm{EG}^{\mathrm{a}}$ & 196 & 8 & $1^{q}$ & $\mathrm{Na}_{2} \mathrm{SO}_{4}$ & [187] \\
\hline Monomers & 60 & $\mathrm{EG}^{\mathrm{a}}$ & 196 & 8 & $1^{q}$ & Zeolithe & [186] \\
\hline Monomers & 61 & $\mathrm{EG}^{\mathrm{a}}$ & 196 & 1 & $1^{q}$ & $\mathrm{Na}_{2} \mathrm{CO}_{3}$ & [203] \\
\hline Monomers & 61 & $\mathrm{EG}^{\mathrm{a}}$ & 196 & 9 & $1^{q}$ & $\mathrm{LiCl}$ & [190] \\
\hline Monomers & 61 & $\mathrm{EG}^{\mathrm{a}}$ & 196 & 9 & $1^{q}$ & $\mathrm{MgCl}_{2}$ & [190] \\
\hline Monomers & 63 & $\mathrm{EG}^{\mathrm{a}}$ & $230-300$ & $0.7-1.3$ & $1^{q}$ & $\mathrm{Co}_{3} \mathrm{O}_{4}$ & [11] \\
\hline Monomers & 64 & $\mathrm{EG}^{\mathrm{a}}$ & $50-175$ & $0.5-2$ & $1^{\mathrm{q}}$ & {$[\mathrm{bmim}] \mathrm{Br}^{\mathrm{t}}$} & [213] \\
\hline Monomers & 65 & $\mathrm{EG}^{\mathrm{a}}$ & $80-200$ & 15 & $1^{q}$ & Zinc stearate & [192] \\
\hline Monomers & 67 & $\mathrm{EG}^{\mathrm{a}}$ & $230-300$ & $0.7-1.3$ & $1^{\mathrm{q}}$ & $\mathrm{ZnO}$ & [11] \\
\hline Monomers & 68 & $\mathrm{EG}^{\mathrm{a}}$ & 190 & 8 & $1^{q}$ & none & [188] \\
\hline Monomers & 70 & $\mathrm{EG}^{\mathrm{a}}$ & 196 & 1 to 8 & $1^{q}$ & Zinc acetate & [205] \\
\hline Monomers & 70 & $\mathrm{EG}^{\mathrm{a}}$ & 196 & 1 to 8 & $1^{q}$ & $\mathrm{Na}_{2} \mathrm{CO}_{3}$ & [205] \\
\hline Monomers & 70 & $\mathrm{NPG}^{\mathrm{b}}$ & $200-220$ & 6 & $1^{q}$ & Zinc acetate & [181] \\
\hline Monomers & 72 & $\mathrm{EG}^{\mathrm{a}}$ & 196 & 9 & $1^{\mathrm{q}}$ & Didymium chloride & [190] \\
\hline Monomers & 73 & $\mathrm{EG}^{\mathrm{a}}$ & 196 & 9 & $1^{q}$ & $\mathrm{ZnCl}_{2}$ & [190] \\
\hline Monomers & 74 & $\mathrm{EG}^{\mathrm{a}}$ & 196 & 1 & $1^{q}$ & Zinc acetate & [171] \\
\hline Monomers & 74 & $\mathrm{EG}^{\mathrm{a}}$ & 196 & 1 & $1^{\mathrm{q}}$ & $\mathrm{Na}_{2} \mathrm{CO}_{3}$ & [171] \\
\hline Monomers & 74 & $\mathrm{EG}^{\mathrm{a}}$ & 196 & 1 & $1^{q}$ & $\mathrm{NaHCO}_{3}$ & [171] \\
\hline Monomers & 74 & $\mathrm{EG}^{\mathrm{a}}$ & 196 & 1 & $1^{\mathrm{q}}$ & $\mathrm{BaOH}$ & [171] \\
\hline Monomers & 74 & $\mathrm{EG}^{\mathrm{a}}$ & $230-300$ & $0.7-1.3$ & $1^{q}$ & $\mathrm{Mn}_{3} \mathrm{O}_{4}$ & [11] \\
\hline Monomers & 75 & $\mathrm{EG}^{\mathrm{a}}$ & 198 & 10 & $1^{q}$ & Zinc acetate & [191] \\
\hline Monomers & 75 & $\mathrm{EG}^{\mathrm{a}}$ & 198 & 10 & $1^{\mathrm{q}}$ & Lead acetate & [191] \\
\hline Monomers & 75 & $\mathrm{EG}^{\mathrm{a}}$ & 198 & 10 & $1^{\mathrm{q}}$ & Manganese acetate & [191] \\
\hline Monomers & 75 & $\mathrm{EG}^{\mathrm{a}}$ & 198 & 10 & $1^{q}$ & Cobalt acetate & [191] \\
\hline Monomers & 75 & $\mathrm{EG}^{\mathrm{a}}$ & 180 & 8 & $1^{\mathrm{q}}$ & Zinc acetate & [183] \\
\hline Monomers & 75 & $\mathrm{EG}^{\mathrm{a}}$ & 180 & 8 & $1^{q}$ & Lead acetate & [183] \\
\hline Monomers & 75 & $\mathrm{EG}^{\mathrm{a}}$ & 180 & 8 & $1^{\mathrm{q}}$ & Manganese acetate & [183] \\
\hline Monomers & 75 & $\mathrm{EG}^{\mathrm{a}}$ & 180 & 8 & $1^{q}$ & Cobalt acetate & [183] \\
\hline Monomers & 76 & $\mathrm{EG}^{\mathrm{a}}$ & 196 & 1 & $1^{\mathrm{q}}$ & Zinc acetate & [203] \\
\hline Monomers & 78 & $\mathrm{EG}^{\mathrm{a}}$ & 190 & 3.5 hours & $1^{\mathrm{q}}$ & $\mathrm{TBD}^{\mathrm{u}}$ & [197] \\
\hline Monomers & 78 & $\mathrm{EG}^{\mathrm{a}}$ & 190 & not given & $1^{q}$ & Cyclic amidine & [200] \\
\hline Monomers & 78 & $\mathrm{EG}^{\mathrm{a}}$ & $80-200$ & 15 & $1^{q}$ & Zinc acetate & [192] \\
\hline Monomers & 79 & $\mathrm{EG}^{\mathrm{a}}$ & 196 & 1.50 & $1^{q}$ & Zn/Al-hydrotalcite & [208] \\
\hline Monomers & 80 & $\mathrm{EG}^{\mathrm{a}}$ & $165-196$ & $0-10$ & $1^{q}$ & $\mathrm{Na}_{2} \mathrm{CO}_{3}$ & [211] \\
\hline Monomers & 80 & $\mathrm{EG}^{\mathrm{a}}$ & $165-196$ & $0-10$ & $1^{q}$ & $\mathrm{NaHCO}_{3}$ & [211] \\
\hline Monomers & 80 & $\mathrm{EG}^{\mathrm{a}}$ & $165-196$ & $0-10$ & $1^{\mathrm{q}}$ & $\mathrm{Na}_{2} \mathrm{SO}_{4}$ & [211] \\
\hline Monomers & 80 & $\mathrm{EG}^{\mathrm{a}}$ & $165-196$ & $0-10$ & $1^{q}$ & $\mathrm{~K}_{2} \mathrm{SO}_{4}$ & [211] \\
\hline Monomers & 80 & $\mathrm{EG}^{\mathrm{a}}$ & $195-220$ & $2.5-3.5$ & $1^{\mathrm{q}}$ & Zinc acetate & [212] \\
\hline Monomers & 80 & $\mathrm{EG}^{\mathrm{a}}$ & 196 & not given & $1^{q}$ & Zinc acetate & [202] \\
\hline Monomers & 80 & $\mathrm{EG}^{\mathrm{a}}$ & 196 & not given & $1^{\mathrm{q}}$ & $\mathrm{Na}_{2} \mathrm{CO}_{3}$ & [202] \\
\hline Monomers & 81 & $\mathrm{EG}^{\mathrm{a}}$ & $230-300$ & $0.7-1.3$ & $1^{\mathrm{q}}$ & $\mathrm{ZnCo}_{2} \mathrm{O}_{4}$ & [11] \\
\hline Monomers & 89 & $\mathrm{EG}^{\mathrm{a}}$ & $230-300$ & $0.7-1.3$ & $1^{q}$ & $\mathrm{CoMn}_{2} \mathrm{O}_{4}$ & [11] \\
\hline Monomers & 90 & $\mathrm{EG}^{\mathrm{a}}$ & 300 & $0.6-1.3$ & 11 & $\gamma-\mathrm{Fe}_{2} \mathrm{O}_{3}$ & [199] \\
\hline Monomers & 92 & $\mathrm{EG}^{\mathrm{a}}$ & 197 & 3 to 4 & $1^{q}$ & Zinc acetate & [206] \\
\hline Monomers & 92 & $\mathrm{EG}^{\mathrm{a}}$ & $230-300$ & $0.7-1.3$ & $1^{\mathrm{q}}$ & $\mathrm{ZnMn}_{2} \mathrm{O}_{4}$ & [11] \\
\hline Monomers & 94 & $\mathrm{EG}^{\mathrm{a}}$ & 450 & $0.4-0.8$ & 153 & none & {$[10]$} \\
\hline Monomers & 98 & $\mathrm{EG}^{\mathrm{a}}$ & 198 & $0.5-2.5$ & $1^{q}$ & Zinc acetate & [210] \\
\hline Monomers & 98 & $\mathrm{EG}^{\mathrm{a}}$ & 198 & $0.5-2.5$ & $1^{q}$ & Lead acetate & [210] \\
\hline Monomers & 98 & $\mathrm{EG}^{\mathrm{a}}$ & 198 & $0.5-2.5$ & $1^{\mathrm{q}}$ & Manganese acetate & [210] \\
\hline
\end{tabular}


Table 3. Reaction conditions and yields of PET glycolysis (1. continue)

\begin{tabular}{|c|c|c|c|c|c|c|c|}
\hline Reaction product & $\begin{array}{l}\text { Yield } \\
{[\%]}\end{array}$ & Reagent & $\begin{array}{c}\text { Reaction } \\
\text { temperature } \\
{\left[{ }^{\circ} \mathrm{C}\right]}\end{array}$ & $\begin{array}{c}\text { Reaction } \\
\text { time } \\
\text { [hours] }\end{array}$ & $\begin{array}{l}\text { Pressure } \\
\text { [bar] }\end{array}$ & Catalyst & Reference \\
\hline Monomers & 98 & $\mathrm{EG}^{\mathrm{a}}$ & 198 & $0.5-2.5$ & $1^{q}$ & Cobalt acetate & [210] \\
\hline Monomers & 100 & $\mathrm{EG}^{\mathrm{a}}$ & reflux & 0.5 & $1^{\mathrm{q}}$ & Zinc acetate & [209] \\
\hline Monomers & not given & $\mathrm{DEG}^{\mathrm{c}}$ & $200-220$ & 4 & $1^{q}$ & Manganese acetate & [176] \\
\hline Monomers & not given & $\mathrm{DEG}^{\mathrm{c}}$ & 180 & 0.1 & $1^{q}$ & Manganese acetate & [219] \\
\hline Monomers & not given & $\mathrm{DEG}^{\mathrm{c}}$ & 240 & 2 & $1^{q}$ & Zinc acetate & [173] \\
\hline Monomers & not given & $\mathrm{EG}^{\mathrm{a}}$ & reflux & 1 & $1^{\mathrm{q}}$ & Zinc acetate & [172] \\
\hline Monomers & not given & $\mathrm{DEG}^{\mathrm{c}}$ & 240 & 0.02 & $1^{\mathrm{q}}$ & Zinc acetate & [218] \\
\hline Monomers & not given & $\mathrm{EG}^{\mathrm{a}}$ & 200 & not given & $1^{q}$ & none & [77] \\
\hline Monomers & not given & $\mathrm{EG}^{\mathrm{a}}$ & 110 & not given & $1^{q}$ & Cobalt acetate & [204] \\
\hline Monomers & not given & $\mathrm{EG}^{\mathrm{a}}$ & $110-190$ & $0-2$ & $1^{q}$ & Manganese acetate & [99] \\
\hline Monomers & not given & $\mathrm{EG}^{\mathrm{a}}$ & 220 & 7 to 8 & $1^{q}$ & Zinc acetate & [201] \\
\hline Monomers & not given & $\mathrm{EG}^{\mathrm{a}}$ & 198 & 3 & $1^{q}$ & Zinc acetate & [207] \\
\hline Monomers & not given & $\mathrm{EG}^{\mathrm{a}}$ & 198 & 3 & $1^{q}$ & Manganese acetate & [207] \\
\hline Monomers & not given & $\mathrm{EG}^{\mathrm{a}}$ & 196 & not given & $1^{\mathrm{q}}$ & $\mathrm{NaHCO}_{3}$ & [202] \\
\hline Monomers & not given & $\mathrm{EG}^{\mathrm{a}}$ & 196 & not given & $1^{q}$ & $\mathrm{Na}_{2} \mathrm{SO}_{4}$ & [202] \\
\hline Monomers & not given & $\mathrm{EG}^{\mathrm{a}}$ & 196 & not given & $1^{\mathrm{q}}$ & $\mathrm{K}_{2} \mathrm{SO}_{4}$ & [202] \\
\hline Monomers & not given & $\mathrm{EG}^{\mathrm{a}}$ & 196 & 1 to 8 & $1^{\mathrm{q}}$ & $\mathrm{NaHCO}_{3}$ & [205] \\
\hline Monomers & not given & $\mathrm{EG}^{\mathrm{a}}$ & 196 & 1 to 8 & $1^{q}$ & $\mathrm{Na}_{2} \mathrm{SO}_{4}$ & [205] \\
\hline Monomers & not given & $\mathrm{EG}^{\mathrm{a}}$ & 196 & 1 to 8 & $1^{q}$ & $\mathrm{~K}_{2} \mathrm{SO}_{4}$ & [205] \\
\hline Monomers & not given & $\mathrm{EG}^{\mathrm{a}}$ & 190 & 8 & $1^{q}$ & Zinc acetate & [184] \\
\hline Monomers & not given & $\mathrm{DEG}^{\mathrm{c}}$ & 190 & 8 & $1^{q}$ & Zinc acetate & [184] \\
\hline Monomers & not given & $\mathrm{PG}^{\mathrm{d}}$ & 190 & 8 & $1^{\mathrm{q}}$ & Zinc acetate & [184] \\
\hline Monomers & not given & $\mathrm{PG}^{\mathrm{d}}$ & 235 & 5 & 2 to 5 & none & [179] \\
\hline Monomers & not given & $\mathrm{PG}^{\mathrm{d}}$ & $190+210$ & $6+1$ & $1^{\mathrm{q}}$ & Tetrabutoxy titanium & [220] \\
\hline Monomers & not given & $\mathrm{PG}^{\mathrm{d}}$ & 190 & 8 & $1^{\mathrm{q}}$ & Zinc acetate & [185] \\
\hline Not given & not given & $\mathrm{DEG}^{\mathrm{c}}$ & 210 & not given & $1^{\mathrm{q}}$ & Zinc acetate & [64] \\
\hline Not given & not given & $\mathrm{PG}^{\mathrm{d}}$ & 210 & not given & $1^{\mathrm{q}}$ & Zinc acetate & [64] \\
\hline Not given & not given & $\mathrm{DPG}^{\mathrm{e}}$ & 210 & not given & $1^{\mathrm{q}}$ & Zinc acetate & [64] \\
\hline Not given & not given & $\mathrm{BG}^{\mathrm{f}}$ & 210 & not given & $1^{\mathrm{q}}$ & Zinc acetate & [64] \\
\hline Not given & not given & $\mathrm{DEG}^{\mathrm{c}}$ & $200-220$ & 6 & $1^{\mathrm{q}}$ & Manganese acetate & [180] \\
\hline Not given & not given & $\mathrm{PG}^{\mathrm{d}}$ & $200-220$ & 6 & $1^{q}$ & Manganese acetate & [180] \\
\hline Not given & not given & TEG $^{\mathrm{g}}$ & $200-220$ & 6 & $1^{\mathrm{q}}$ & Manganese acetate & [180] \\
\hline Not given & not given & $E^{\mathrm{a}}$ & 190 & 8 & $1^{\mathrm{q}}$ & Zinc acetate & [182] \\
\hline $\begin{array}{l}\text { Oligomers } \\
{\left[2840 \mathrm{~g} \cdot \mathrm{mol}^{-1}\right]}\end{array}$ & 17 & $\mathrm{PTMO}^{\mathrm{h}}$ & $200-270$ & 8 & $1^{\mathrm{q}}$ & Titanium tetra isopropoxide & [193] \\
\hline $\begin{array}{l}\text { Oligomers } \\
{\left[1380 \mathrm{~g} \cdot \mathrm{mol}^{-1}\right]}\end{array}$ & 18 & $\mathrm{PEG}^{\mathrm{i}}$ & $200-270$ & 8 & $1^{\mathrm{q}}$ & Titanium tetra isopropoxide & {$[193]$} \\
\hline $\begin{array}{l}\text { Oligomers } \\
{\left[1120 \mathrm{~g} \cdot \mathrm{mol}^{-1}\right]}\end{array}$ & 20 & TEEG $^{\mathrm{j}}$ & $200-270$ & 8 & $1^{q}$ & Titanium tetra isopropoxide & [193] \\
\hline $\begin{array}{l}\text { Oligomers } \\
{\left[2300 \mathrm{~g} \cdot \mathrm{mol}^{-1}\right]}\end{array}$ & 23 & Pluronic L $31^{\mathrm{k}}$ & $200-270$ & 8 & $1^{q}$ & Titanium tetra isopropoxide & [193] \\
\hline $\begin{array}{l}\text { Oligomers } \\
{\left[1131 \mathrm{~g} \cdot \mathrm{mol}^{-1}\right]}\end{array}$ & not given & TEA $^{1}$ & $190-200$ & 3 & $1^{\mathrm{q}}$ & Manganese acetate & {$[175]$} \\
\hline $\begin{array}{l}\text { Oligomers } \\
{\left[1360 \mathrm{~g} \cdot \mathrm{mol}^{-1}\right]}\end{array}$ & not given & BHET $^{\mathrm{m}}$ & 250 & 2 & $1^{\mathrm{q}}$ & Zinc acetate & [174] \\
\hline $\begin{array}{l}\text { Oligomers } \\
{\left[1450 \mathrm{~g} \cdot \mathrm{mol}^{-1}\right]}\end{array}$ & not given & $\mathrm{EG}^{\mathrm{a}}$ & 270 & not given & $1^{q}$ & none & [214] \\
\hline $\begin{array}{l}\text { Oligomers } \\
{\left[1450 \mathrm{~g} \cdot \mathrm{mol}^{-1}\right]}\end{array}$ & not given & $\mathrm{EG}^{\mathrm{a}}$ & 270 & not given & $1^{\mathrm{q}}$ & none & {$[215]$} \\
\hline $\begin{array}{l}\text { Oligomers } \\
{\left[1450 \mathrm{~g} \cdot \mathrm{mol}^{-1}\right]}\end{array}$ & not given & $\mathrm{EG}^{\mathrm{a}}$ & 270 & not given & $1^{\mathrm{q}}$ & none & {$[217]$} \\
\hline $\begin{array}{l}\text { Oligomers } \\
{\left[1648 \mathrm{~g} \cdot \mathrm{mol}^{-1}\right]}\end{array}$ & not given & $\mathrm{PEG}^{\mathrm{i}}$ & 190-200 & 8 & $1^{\mathrm{q}}$ & none & [189] \\
\hline $\begin{array}{l}\text { Oligomers } \\
{\left[1800 \mathrm{~g} \cdot \mathrm{mol}^{-1}\right]}\end{array}$ & not given & $\mathrm{EG}^{\mathrm{a}}$ & 270 & not given & $1^{q}$ & none & {$[216]$} \\
\hline $\begin{array}{l}\text { Oligomers } \\
{\left[210-595 \mathrm{~g} \cdot \mathrm{mol}^{-1}\right]}\end{array}$ & not given & $\mathrm{EG}^{\mathrm{a}}$ & $170+190$ & 1 to 6 & $1^{q}$ & Zinc acetate & [199] \\
\hline
\end{tabular}


Table 3. Reaction conditions and yields of PET glycolysis (2. continue)

\begin{tabular}{|l|c|c|c|c|c|c|c|}
\hline Reaction product & $\begin{array}{c}\text { Yield } \\
{[\%]}\end{array}$ & Reagent & $\begin{array}{c}\text { Reaction } \\
\text { temperature } \\
{\left[{ }^{\circ} \mathbf{C}\right]}\end{array}$ & $\begin{array}{c}\text { Reaction time } \\
{[\text { hours }]}\end{array}$ & $\begin{array}{c}\text { Pressure } \\
{[\text { bar }]}\end{array}$ & Catalyst & Reference \\
\hline $\begin{array}{c}\text { Oligomers } \\
{\left[300-500 \mathrm{~g} \cdot \mathrm{mol}^{-1}\right]}\end{array}$ & not given & $\mathrm{DEG}^{\mathrm{c}}$ & $200-220$ & 4 & $1^{\mathrm{q}}$ & Manganese acetate & {$[177]$} \\
\hline $\begin{array}{c}\text { Oligomers } \\
{\left[450-510 \mathrm{~g} \cdot \mathrm{mol}^{-1}\right]}\end{array}$ & not given & $\mathrm{DEG}^{\mathrm{c}}$ & 210 & 4 & $1^{\mathrm{q}}$ & Manganese acetate & {$[178]$} \\
\hline $\begin{array}{c}\text { Oligomers } \\
{\left[497 \mathrm{~g} \cdot \mathrm{mol}^{-1}\right]}\end{array}$ & not given & $\mathrm{BD}^{\mathrm{n}}$ & not given & not given & $1^{\mathrm{q}}$ & none & {$[221]$} \\
\hline $\begin{array}{c}\text { Oligomers } \\
{\left[534 \mathrm{~g} \cdot \mathrm{mol}^{-1}\right]}\end{array}$ & not given & $\mathrm{DEG}^{\mathrm{c}}$ & $190-200$ & 8 & $1^{\mathrm{q}}$ & none & {$[189]$} \\
\hline $\begin{array}{c}\text { Oligomers } \\
{\left[881 \mathrm{~g} \cdot \mathrm{mol}^{-1}\right]}\end{array}$ & not given & $\mathrm{TEG}^{\mathrm{g}}$ & not given & not given & $1^{\mathrm{q}}$ & none & {$[221]$} \\
\hline $\begin{array}{c}\text { Oligomers } \\
{\left[900 \mathrm{~g} \cdot \mathrm{mol}^{-1}\right]}\end{array}$ & not given & $\mathrm{DEA}^{\mathrm{o}}$ & $170-210$ & 3 to 4 & $1^{\mathrm{q}}$ & Manganese acetate & {$[195]$} \\
\hline $\begin{array}{c}\text { Oligomers } \\
{\left[900 \mathrm{~g} \cdot \mathrm{mol}^{-1}\right]}\end{array}$ & not given & $\mathrm{TEA}^{1}$ & $170-210$ & 3 to 4 & $1^{\mathrm{q}}$ & Manganese acetate & {$[195]$} \\
\hline $\begin{array}{c}\text { Oligomers } \\
{\left[900 \mathrm{~g} \cdot \mathrm{mol}^{-1}\right]}\end{array}$ & not given & $\mathrm{DEA}^{\mathrm{o}}$ & $180-210$ & 3 to 4 & high pressure & Manganese acetate & {$[196]$} \\
\hline $\begin{array}{c}\text { Oligomers } \\
{\left[900 \mathrm{~g} \cdot \mathrm{mol}^{-1}\right]}\end{array}$ & not given & $\mathrm{TEA}^{1}$ & $180-210$ & 3 to 4 & high pressure & Manganese acetate & {$[196]$} \\
\hline $\begin{array}{c}\text { Oligomers } \\
{\left[900 \mathrm{~g} \cdot \mathrm{mol}^{-1}\right]}\end{array}$ & not given & $\mathrm{DEG}^{\mathrm{c}}$ & $180-210$ & 3 to 4 & high pressure & Manganese acetate & {$[196]$} \\
\hline $\begin{array}{c}\text { Oligomers } \\
{\left[900 \mathrm{~g} \cdot \mathrm{mol}^{-1}\right]}\end{array}$ & not given & $\mathrm{TMP}^{\mathrm{p}}$ & $180-210$ & 3 to 4 & high pressure & Manganese acetate & {$[196]$} \\
\hline $\begin{array}{c}\text { Oligomers } \\
{\left[957 \mathrm{~g} \cdot \mathrm{mol}^{-1}\right]}\end{array}$ & not given & $\mathrm{DEA}^{\mathrm{o}}$ & $190-200$ & 3 & $1^{\mathrm{q}}$ & Manganese acetate & {$[175]$} \\
\hline
\end{tabular}

${ }^{\mathrm{a} E G}$ : Ethylene glycol. ${ }^{\mathrm{b}} \mathrm{NPG}$ : Neopentyl glycol. ${ }^{\mathrm{c}} \mathrm{DEG}$ : Diethylene glycol. ${ }^{\mathrm{d}} \mathrm{PG}$ : Propylene glycol. ${ }^{\mathrm{e}} \mathrm{DPG}$ : Dipropylene glycol. ${ }^{\mathrm{f}} \mathrm{BG}$ : Buty-

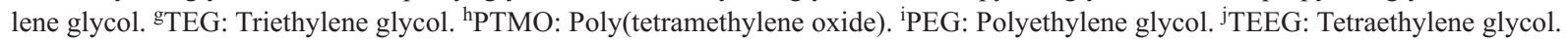

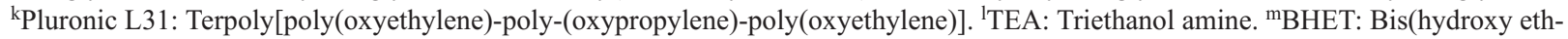
ylene) terephthalate. ${ }^{\mathrm{n} B D}$ : Butanediol. ${ }^{\circ} \mathrm{DEA}$ : Diethanol amine. ${ }^{\mathrm{p} T M P}$ : Trimethylol propane. ${ }^{\mathrm{q}}$ No pressure was given in the experimental section, thus, atmospheric pressure was assumed. ${ }^{\mathrm{r}} \mathrm{Cu}(\mathrm{OAc})_{2}-[\mathrm{Bmim}][\mathrm{OAc}]:$ 1-butyl-3-methylimidazolium acetate-promoted copper acetate. ${ }^{\mathrm{s}} \mathrm{Zn}(\mathrm{OAc})_{2}$-[Bmim] $[\mathrm{OAc}]:$ 1-Butyl-3-methylimidazolium acetate-promoted zinc acetate. ${ }^{\mathrm{t}}[\mathrm{bmim}] \mathrm{Br}$ : 1-butyl-3-methylimidazolium bromide. "TBD: 1,5,7-triazabicyclo[4.4.0]dec-5-ene.

These results were confirmed by Ghaemy and Moassaddegh as well as Goje and Mishra [184, 192,211]. Pingale et al. [191] also studied the influence of different cations, namely zinc, lithium, didymium, magnesium and iron, on the catalytic effect of respective chlorides in the glycolysis of PET. They found zinc chloride to be the most effective catalyst yielding $73 \%$ BHET, followed by didymium chloride, magnesium chloride, lithium chloride and ferric chloride. In contrast, Carné Sánchez and Collinson [193] studied the catalytic effect of zinc catalysts on PET-glycolysis with different anions, namely acetate, stearate and sulfate. They found zinc acetate to be the most effective catalyst (Table 3, 78\% BHET), followed by zinc stearate (Table 3, 65\% BHET) and finally zinc sulfate (Table 3, 25\% BHET). Analogously, Pingale and Shukla [172], Duque-Ingunza and coworkers [203, 204, 206, 212] studied PET-glycolysis using different sodium catalysts with different anions (carbonate, bicarbonate and sulfate). The effectiveness of the sodium catalysts on glycolysis yielding BHET decreased in the following order: sodium bicarbonate $>$ sodium carbonate $>$ sodium sulfate.

Finally, there are only few reports about the use of very special catalyst for glycolysis. Al-Sabagh et al. [195] and Alnaqbi et al. [214] applied ionic liquids (1-butyl-3-methylimidazolium bromide or 1-butyl3-methylimidazolium acetate as co-catalyst) for complete glycolysis of PET. Further, Fukushima and coworkers $[198,201]$ used cyclic amidine catalysts (e.g. 1,5,7-triazabicyclo[4.4.0]dec-5-ene, TBD) to de-polymerize PET].

Other authors used very specific catalyst like tetrabutoxy titanium, titanium tetraisopropoxide, zeolite, $\mathrm{Zn} / \mathrm{Al}$-hydrotalcite, $\mathrm{ZnO}$, metal oxide spinels $\left(\mathrm{Co}_{3} \mathrm{O}_{4}\right.$ and $\left.\mathrm{Mn}_{3} \mathrm{O}_{4}\right)$, mixed metal oxide spinels $\left(\mathrm{ZnMn}_{2} \mathrm{O}_{4}\right.$, $\left.\mathrm{CoMn}_{2} \mathrm{O}_{4}, \mathrm{ZnCo}_{2} \mathrm{O}_{4}\right)$ and $\gamma-\mathrm{Fe}_{2} \mathrm{O}_{3}$ as alternatives to common catalysts [11, 187, 200, 210, 221].

In addition, glycolysis leads to the formation of undesired cyclic oligomers [128]. The monomers and low molecular weight oligomers obtained from glycolysis of PET were generally used for impaired ap- 
plications, such as modifiers for PVC or other polymer composites [183, 190, 208, 222]. Further, these glycolyized products were applied for synthesis of co-polymers of undefined composition $[174,179$, $181,182,194,219]$.

\subsubsection{Aminolysis/ammonolysis}

Aminolysis and ammonolyis were developed, since the reactivity of the amine-group is higher than the hydroxyl-group in glycols or alcohols used in glycolysis or alcoholysis of PET [223, 224]. Further, drawbacks of other conventional chemical recycling methods (hydrolysis, methanolysis) like high temperature and high pressure conditions were aimed of being avoided by aminolysis and ammonolysis. After depolymerization, in general, the reaction products were applied as curing agents for epoxy resins, as components for polyurethane synthesis or as plasticizers [225-228].

The general reaction scheme of aminolysis and ammonolysis is depicted in Figure 6. Here, corresponding diamides of terephthalic acid are obtained. Aminolysis and ammonolyis are generally conducted at temperatures between 25 and $190^{\circ} \mathrm{C}$. Generally no high pressure is applied and reaction time may vary from few hours to several days (Table 4). The chemicals such as alkyl amines or liquid ammonia are used in excess for PET de-polymerization (Table 4). Aminolysis and ammonolysis mainly yielded the corresponding monomeric amides of terephthalic acid [223, 226-234].

The de-polymerization agent, which was mainly applied, was ethanol amine (EA, Table 4). EA was used to synthesize the bi-functional monomer bis(2-hydroxyl-ethylene) terephthalamide (BHETPA) in yields between 62 to $91 \%$ for further polymer syntheses (Table 4) [223, 224, 230, 232]. Further, but less used chemicals for aminolysis or ammonolysis of PET are methyl amine (MA), liquor ammonia $\left(\mathrm{NH}_{3}\right)$ and ethylene diamine (EDA). As in case of EA, these chemicals lead to the formation of corresponding bi-functional monomers of terephthalic acid, which could be applied as curing agents for epoxy resins [227, 228, 233]. Hoang and Dang used excess EDA to depolymerize PET to low molecular weight oligomers $\left(250-820 \mathrm{~g} \cdot \mathrm{mol}^{-1}\right.$, Table 4$)$. Removal of solid residues by filtration and additional purification gave these oligomers in yields of $30 \%$. These were assumed to be used for synthesis of polyamides or polyimides [235]. Only little use of hydrazine hydrate, triethylene tetramine, tetraethylene pentamine, allylamine, di- or triethanol amine for aminolysis of PET was made. With these chemicals corresponding diamides of terephthalic acid were obtained, which were consecutively applied as additives in concrete mixture or used for further synthesis of antibacterial chemicals [230, 233, 234].

As for glycolysis, different catalysts were also applied for aminolysis, ammonolysis. Mainly metal acetates were used (zinc acetate, sodium acetate, potassium acetate,Table 4) [226, 227, 231, 232]. Shukla and Harad studied the effect of sodium-, potassium acetate and acetic acid on efficiency of PET-aminolysis. They found sodium acetate as the most efficient catalyst, followed by potassium acetate and acetic acid [232]. More et al. [224] compared zinc acetate and sodium acetate for PET-aminolysis and found (as in case of glycolysis) zinc acetate to be more efficient for aminolysis reaction. Mittal et al. [228] compared aminolysis and ammonolysis using cetyl am-

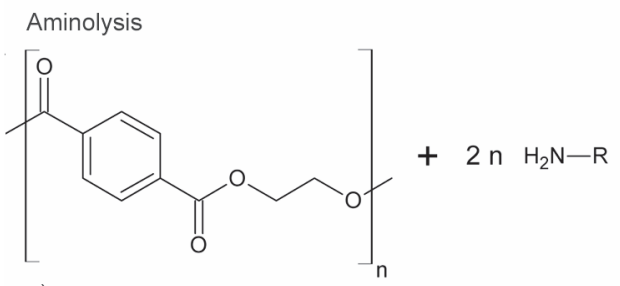

a)

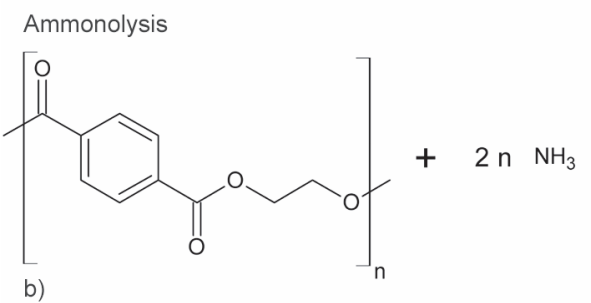

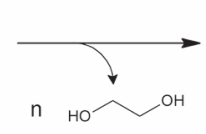

n<smiles>[R]NC(=O)c1ccc(C(=O)NC)cc1</smiles>
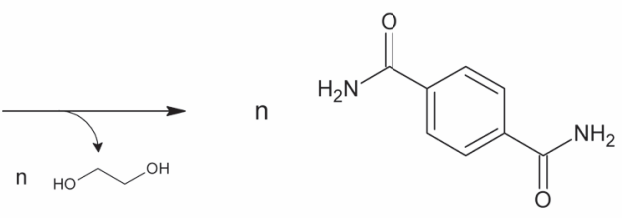

Figure 6. Chemical recycling methods of PET ((a) Aminolysis, (b) Ammonolysis) 
Table 4. Reaction conditions and yields of PET aminolysis, ammonolysis

\begin{tabular}{|c|c|c|c|c|c|c|c|}
\hline Reaction product & $\begin{array}{l}\text { Yield } \\
{[\%]}\end{array}$ & Reagent & $\begin{array}{c}\text { Reaction } \\
\text { temperature } \\
{\left[{ }^{\circ} \mathrm{C}\right]}\end{array}$ & $\begin{array}{l}\text { Reaction } \\
\text { time [min] }\end{array}$ & $\begin{array}{l}\text { Pressure } \\
\text { [bar] }\end{array}$ & Catalyst & Reference \\
\hline Monomers & 38 & $\mathrm{NH}_{3}$ & 40 & $180-2700$ & $1^{\mathrm{h}}$ & Cetyl ammonium bromide & [227] \\
\hline Monomers & 62 & $\mathrm{EA}^{\mathrm{a}}$ & 190 & 2 to 12 & 1 & Dibutyltinoxide & [222] \\
\hline Monomers & 75 & $\mathrm{EA}^{\mathrm{a}}$ & 160 & 2 to 12 & $1^{\mathrm{h}}$ & Sodium acetate & [223] \\
\hline Monomers & 76 & $\mathrm{EA}^{\mathrm{a}}$ & 172 & 18 & $1^{\mathrm{h}}$ & Acetic acid & [231] \\
\hline Monomers & 81 & $\mathrm{EA}^{\mathrm{a}}$ & 160 & 2 to 12 & $1^{\mathrm{h}}$ & Zinc acetate & [223] \\
\hline Monomers & 85 & $\mathrm{EA}^{\mathrm{a}}$ & 172 & 18 & $1^{\mathrm{h}}$ & Sodium acetate & {$[228]$} \\
\hline Monomers & 86 & Hydrazin hydrate & 114 & 20 & $1^{\mathrm{h}}$ & none & [230] \\
\hline Monomers & 87 & $\mathrm{EA}^{\mathrm{a}}$ & 172 & 18 & $1^{\mathrm{h}}$ & Potassium sulphate & [231] \\
\hline Monomers & 91 & $\mathrm{EA}^{\mathrm{a}}$ & 172 & 18 & $1^{\mathrm{h}}$ & Sodium acetate & [231] \\
\hline Monomers & 94 & $\mathrm{MA}^{\mathrm{b}}$ & 40 & $180-2700$ & $1^{\mathrm{h}}$ & Cetyl ammonium bromide & [227] \\
\hline Monomers & not given & Allylamine & 180 & not given & $15-20$ & none & [233] \\
\hline Monomers & not given & $\mathrm{EA}^{\mathrm{a}}$ & 180 & not given & $15-20$ & none & [233] \\
\hline Monomers & not given & $\mathrm{DEA}^{\mathrm{c}}$ & 180 & not given & $15-20$ & none & [233] \\
\hline Monomers & not given & TEA $^{\mathrm{d}}$ & 180 & not given & $15-20$ & none & [233] \\
\hline Monomers & not given & $\mathrm{EDA}^{\mathrm{e}}$ & $\begin{array}{l}\text { Ambient } \\
\text { temperature }\end{array}$ & $0-300$ & $1^{\mathrm{h}}$ & none & [225] \\
\hline Monomers & not given & $\mathrm{MA}^{\mathrm{b}}$ & 40 & $180-2700$ & $1^{\mathrm{h}}$ & Cetyl ammonium bromide & [232] \\
\hline Monomers & not given & $\mathrm{NH}_{3}$ & 40 & $180-2700$ & $1^{\mathrm{h}}$ & Cetyl ammonium bromide & [232] \\
\hline Monomers & not given & $\mathrm{NH}_{3}$ & $\begin{array}{l}\text { Ambient } \\
\text { temperature }\end{array}$ & $180-2700$ & $1^{\mathrm{h}}$ & Zinc acetate & [226] \\
\hline Monomers & quantitative & TETA $^{f}$ & $130-140$ & 18 & $1^{\mathrm{h}}$ & none & [229] \\
\hline Monomers & quantitative & TEEPA $^{\mathrm{g}}$ & $130-140$ & 18 & $1^{\mathrm{h}}$ & none & [229] \\
\hline $\begin{array}{l}\text { Oligomers } \\
{\left[250-820 \mathrm{~g} \cdot \mathrm{mol}^{-1}\right]}\end{array}$ & 30 & $\mathrm{EDA}^{\mathrm{e}}$ & 100 & 42 & $1^{\mathrm{h}}$ & none & [234] \\
\hline
\end{tabular}

${ }^{a}$ EA: Ethanol amine. ${ }^{b}$ MA: Methyl amine. ${ }^{c}$ DEA: Diethanol amine. ${ }^{\mathrm{d}}$ TEA: Triethanol amine. ${ }^{e} \mathrm{EDA}$ : Ethylene diamine.

${ }^{\mathrm{f}}$ TETA: Triethylene tetramine. ${ }^{\mathrm{g}}$ TEEPA: Tetraethylene pentamine. ${ }^{\mathrm{h}}$ No specific pressure was given in the experimental section, thus, atmospheric pressure was assumed.

monium bromide as catalyst. Generally, both reaction types yielded less monomeric reaction product without catalyst. Using the catalyst, they found a higher yield for aminolysis (94\%, Table 4) than for ammonolysis (38\%, Table 4). Compared to the aforementioned catalysts, di-butyl tinoxide used by Tawfik and Eskander [223] was less efficient for aminolysis of PET (Table 4).

All described chemical recycling methods require either high pressure apparatus (hydrolysis, methanolysis) or toxic chemicals (alkyl amines, glycols, methanol, sulfuric acid, nitric acid) to yield mainly monomers of PET. In case of glycolysis precise process control is of crucial importance either to prevent re-polymerization or other side-reactions $[8,9$, $148,153,226]$.<smiles>CC(=O)c1ccc(C(=O)OCCOCCOCCOC(=O)O)cc1</smiles>

Figure 7. Blocking chain scission of PET using adipic acid [95]

\subsubsection{Controlled de-polymerization using blocking chain scission}

This method was developed by Geyer et al. [95] as an alternative chemical recycling method which prevents uncontrolled de-polymerization. Furthermore, it overcomes some of the drawbacks of the methods described in earlier sections: The need of high temperature and high pressure conditions, the use of toxic and environmentally problematic chemicals (either the de-polymerization agents or the catalysts) and considerable amounts of solvents. The general reaction scheme of blocking chain scission is depicted in Figure 7.

PET was melt-mixed with stoichiometric amounts of adipic acid to yield tailored oligomers of defined molecular weight. With this approach defined oligo-<smiles>O=C(O)CCCCC(=O)OCCOC(=O)c1ccc(C(=O)O[Na])cc1</smiles> 
mers of molecular weights in the range of 960 $23500 \mathrm{~g} \cdot \mathrm{mol}^{-1}$ were readily prepared, which was not possible with former chemical recycling methods [95]. However, this method requires sorted PET-material, which has to be free of contaminants or other polymer species.

Geyer et al. [236] used these defined building blocks to synthesize novel block-co-polyesters with tailored surface properties. By the combination of defined PET- and PEN-oligomers PET-PEN-block-co-polyesters with tailored block segment composition were prepared. In dependence of the block segment composition it was possible to control the dispersive surface energy and specific desorption energy of these block-co-polyesters. By tailoring these surface properties, these PET-PEN-block-co-polyesters could be applied as compatibilizing agent to prepare transparent blends of PET and PEN. Since PET and PEN are originally immiscible, leading to opaque products, in contrast, such blends of PET and PEN made transparent could now be used for high-value added applications. For example, as encapsulating material for organic photovoltaics, which require maximum transparency for optimum efficiency of the solar cell. Furthermore, such blends exhibit an improved storage modulus and higher glass transition temperatures compared to pure PET, which makes them especially interesting as materials for hot re-fillable or pasteurizable food packaging [236, 237].

\section{Conclusions}

A thorough review of conventional and exceptional PET-recycling with a special emphasis on on chemical methods has been given. Energetic recycling methods like incineration or pyrolysis lead to a downcycling of PET (due to thermal degradation), using its reaction products either directly (use of the released heat of combustion) or indirectly (use of obtained chemicals as alternative for fossil fuels) for energy recovery. Although carbonization produces coal, active carbon or adsorbents for chemicals as more ecofriendly applications, again, due to thermal degradation, this method remains a downcycling of PET. On the other hand, thermo-mechanical recycling of PET leads to a downcycling of the material either, since thermal conditions caused thermal degradation of PET and reduced physical and mechanical properties of the recycled PET. In contrast, chemical recycling methods, which provided complete de-polymeriza- tion of PET yielding monomers, enabled value-added re-usability of reaction products like the synthesis of virgin PET. However, these methods require high temperature and high pressure apparatus. Further, large amounts of chemicals are consumed for de-polymerization and consecutive separation as well as purification steps. Thus, such chemical recycling methods impose toxic and ecological issues. The alternative of producing PET-oligomers with chemical recycling methods is not well solved either. Although glycolysis is generally conducted without high pressure conditions, again, considerable quantities of chemicals are required for partial de-polymerization, separation and purification steps of the reaction products. Hence, as in case of complete de-polymerization of PET, partial de-polymerization imposes toxic and ecological issues either. Further, these less well-defined low molecular weight oligomers are within a heterogeneous mixture of by-products such as monomers, di- or trimers. Moreover, these heterogeneous reaction products are generally used for impaired applications such as dispersants or plasticizers. An alternative chemical recycling of PET was given by the controlled de-polymerization of PET using blocking chain scission with defined amounts of the de-polymerization agent. This method produced PET-oligomers of well-defined molecular weights in a greater range than existing chemical methods (like glycolysis). These building-blocks enabled the synthesis of tailored block-co-polyesters as potential compatibilizers to produce transparent PET-PEN-blends, which are suitable as an encapsulation material for photovoltaic cells or for hot refillable and pasteurizable food packaging.

\section{References}

[1] Paszun D., Spychaj T.: Chemical recycling of poly (ethylene terephthalate). Industrial and Engineering Chemistry Research, 36, 1373-1383 (1997).

DOI: $10.1021 /$ ie $960563 \mathrm{c}$

[2] Lepoittevin B., Roger P.: Poly(ethylene terephthalate). in 'Handbook of engineering and speciality thermoplastics: Polyethers and polyesters' (eds.: Thomas S., Visakh P. M.) Wiley, Hoboken, 97-126 (2011). DOI: $10.1002 / 9781118104729 . c h 4$

[3] Chilton T., Burnley S., Nesaratnam S.: A life cycle assessment of the closed-loop recycling and thermal recovery of post-consumer PET. Resources, Conservation and Recycling, 54, 1241-1249 (2010). DOI: $10.1016 /$ j.resconrec.2010.04.002 
[4] Farmer N.: The future: Global trends and analysis for the international packaging market in relation to the speed of impact of packaging innovation and likely material changes. in 'Trends in packaging of food, beverages and other fast-moving consumer goods (FMCG)' (ed.: Farmer N.), Elsevier, Oxford, 288-312 (2013).

[5] Intini F., Kühtz S.: Recycling in buildings: an LCA case study of a thermal insulation panel made of polyester fiber, recycled from post-consumer PET bottles. International Journal of Life Cycle Assessment, 16, 306315 (2011).

DOI: $10.1007 / \mathrm{s} 11367-011-0267-9$

[6] Amienyo D., Gujba H., Stichnothe H., Azapagic A.: Life cycle environmental impacts of carbonated soft drinks. International Journal of Life Cycle Assessment, 18, 77-92 (2013). DOI: $10.1007 / \mathrm{s} 11367-012-0459-y$

[7] Almeida C. M. V. B., Rodrigues A. J. M., Bonilla S. H., Giannetti B. F. J.: Emergy as a tool for ecodesign: Evaluating materials selection for beverage packages in Brazil. Journal of Cleaner Production, 18, 32-43 (2010). DOI: 10.1016/j.jclepro.2009.03.019

[8] Awaja F., Pavel D.: Recycling of PET. European Polymer Journal, 41, 1453-1477 (2005). DOI: 10.1016/j.eurpolymj.2005.02.005

[9] Dutt K., Soni R. K.: A review on synthesis of value added products from polyethylene terephthalate (PET) waste. Polymer Science Series B, 55, 430-452 (2013). DOI: $10.1134 / \mathrm{S} 1560090413070075$

[10] Imran M., Kim B-K., Han M., Cho B. G., Kim D. H.: Sub- and supercritical glycolysis of polyethylene terephthalate (PET) into the monomer bis(2-hydroxyethyl) terephthalate (BHET). Polymer Degradation and Stability, 95, 1685-1693 (2010)

DOI: $10.1016 /$ j.polymdegradstab.2010.05.026

[11] Imran M., Kim D. H., Al-Masry W. A., Mahmood A., Hassan A., Haider S., Ramay S. M.: Manganese-, cobalt-, and zinc-based mixed-oxide spinels as novel catalysts for the chemical recycling of poly(ethylene terephthalate) via glycolysis. Polymer Degradation and Stability, 98, 904-915 (2013).

DOI: $10.1016 /$ j.polymdegradstab.2013.01.007

[12] Lorenzetti C., Manaresi P., Berti C., Barbiroli G.: Chemical recovery of useful chemicals from polyester (PET) waste for resource conservation: A survey of state of the art. Journal of Polymers and the Environment, 14, 89-101 (2006).

DOI: $10.1007 / \mathrm{s} 10924-005-8711-1$

[13] Nikles D. E., Farahat M. S.: New motivation for the depolymerization products derived from poly(ethylene terephthalate) (PET) waste: A review. Macromolecular Materials and Engineering, 290, 13-30 (2005).

DOI: $10.1002 /$ mame.200400186
[14] Sinha V., Patel M. R., Patel J. V.: PET waste management by chemical recycling: A review. Journal of Polymers and the Environment, 18, 8-25 (2010).

DOI: $10.1007 / \mathrm{s} 10924-008-0106-7$

[15] Achilias D. S.: Polymer degradation under microwave irradiation. in 'Advances in polymer science' (eds.: Abe A., Albertsson A-C., Coates G. W., Genzer J., Kobayashi S., Lee K-S., Leibler L., Long T. E., Möller M., Okay O., Percec V., Tang B. Z., Terentjev E. M., Theato P., Vicent M. J., Voit B., Wiesner U., Zhang X.) Springer, Berlin, 1-38 (2014).

DOI: $10.1007 / 122014292$

[16] de Marco I., Caballero B., Torres A., Laresgoiti M. F., Chomón M. J., Cabrero M. A.: Recycling polymeric wastes by means of pyrolysis. Journal of Chemical Technology and Biotechnology, 77, 817-824 (2002). DOI: $10.1002 /$ jetb. 636

[17] Jung C. G., Fontana A.: Production of gaseous and liquid fuels by pyrolysis and gasification of plastics: technological approach. in 'Feedstock recycling and pyrolysis of waste plastics: Converting waste plastics into diesel and other fuels' (eds.: Scheirs J., Kaminsky W.) Wiley, Chichester 266-267 (2006).

[18] López A., de Marco I., Caballero B. M., Laresgoiti M. F., Adrados A.: Dechlorination of fuels in pyrolysis of PVC containing plastic wastes. Fuel Processing Technology, 92, 253-260 (2011). DOI: $10.1016 /$ j.fuproc.2010.05.008

[19] Lopez-Urionabarrenechea A., de Marco I., Caballero B. M., Laresgoiti M. F., Adrados A.: Catalytic stepwise pyrolysis of packaging plastic waste. Journal of Analytical and Applied Pyrolysis, 96, 54-62 (2012). DOI: 10.1016/j.jaap.2012.03.004

[20] Yoshioka T., Handa T., Grause G., Lei Z., Inomata H., Mizoguchi T.: Effects of metal oxides on the pyrolysis of poly(ethylene terephthalate). Journal of Analytical and Applied Pyrolysis, 73, 139-144 (2005).

DOI: $10.1016 /$ j.jaap.2005.01.004

[21] Straka P., Buchtele J., Kováŕová J.: Co-pyrolysis of waste polymers with coal. Macromolecular Symposia, 135, 19-23 (1998).

DOI: $10.1002 /$ masy. 19981350105

[22] Adrados A., de Marco I., Caballero B. M., López A., Laresgoiti M. F., Torres A.: Pyrolysis of plastic packaging waste: A comparison of plastic residuals from material recovery facilities with simulated plastic waste. Waste Management, 32, 826-832 (2012).

DOI: $10.1016 /$ j.wasman.2011.06.016

[23] Andel L., Kusy J., Vales J., Safarova M.: Pyrolysis process of waste polyethyleneterephtalate. Chemical Product and Process Modeling, 4, 1-6 (2009) DOI: $\underline{10.2202 / 1934-2659.1321}$ 
[24] Kulesza K., German K.: Chlorinated pyrolysis products of co-pyrolysis of poly(vinyl chloride) and poly(ethylene terephthalate). Journal of Analytical and Applied Pyrolysis, 67, 123-134 (2003).

DOI: $10.1016 / \mathrm{S} 0165-2370(02) 00057-8$

[25] Kumagai S., Grause G., Kameda T., Yoshioka T.: Simultaneous recovery of benzene-rich oil and metals by steam pyrolysis of metal-poly(ethylene terephthalate) composite waste. Environmental Science and Technology, 48, 3430-3437 (2014).

DOI: $10.1021 / \mathrm{es} 405047 \mathrm{j}$

[26] Kumagai S., Grause G., Kameda T., Yoshioka T.: Recovery of benzene-rich oil from the degradation of metaland metal oxide-containing poly(ethylene terephthalate) composites. Journal of Material Cycles and Waste Management, 16, 282-290 (2014).

DOI: $10.1007 / \mathrm{s} 10163-013-0194-\mathrm{X}$

[27] Miller S. J., Shah N., Huffman G. P.: Conversion of waste plastic to lubricating base oil. Energy and Fuels, 19, 1580-1586 (2005). DOI: 10.1021/ef049696y

[28] Mlynková B., Hájeková E., Bajus M.: Copyrolysis of oils/waxes of individual and mixed polyalkenes cracking products with petroleum fraction. Fuel Processing Technology, 89, 1047-1055 (2008).

DOI: 10.1016/j.fuproc.2008.04.007

[29] Siddiqui M. N., Redhwi H. H.: Pyrolysis of mixed plastics for the recovery of useful products. Fuel Processing Technology, 90, 545-552 (2009).

DOI: $10.1016 /$ j.fuproc.2009.01.003

[30] Yoshioka T., Grause G., Eger C., Kaminsky W., Okuwaki A.: Pyrolysis of poly(ethylene terephthalate) in a fluidised bed plant. Polymer Degradation and Stability, 86, 499-504 (2004).

DOI: $10.1016 /$ j.polymdegradstab.2004.06.001

[31] Hujuri U., Ghoshal A. K., Gumma S.: Temperature-dependent pyrolytic product evolution profile for polyethylene terephthalate. Journal of Applied Polymer Science, 130, 3993-4000 (2013).

DOI: 10.1002/APP.39681

[32] Ahmadinia E., Zargar M., Karim M. R., Abdelaziz M., Ahmadinia E.: Performance evaluation of utilization of waste polyethylene terephthalate (PET) in stone mastic asphalt. Construction and Building Materials, 36, 984989 (2012).

DOI: $10.1016 /$ j.conbuildmat.2012.06.015

[33] Hassani A., Ganjidoust H., Maghanaki A. A.: Use of plastic waste (poly-ethylene terephthalate) in asphalt concrete mixture as aggregate replacement. Waste Management and Research, 23, 322-327 (2005). DOI: $10.1177 / 0734242 X 05056739$

[34] Mendes L. C., Dias M. L., Rodrigues T. C.: Chemical recycling of PET waste with multifunctional pentaerythrytol in the melt state. Journal of Polymers and the Environment, 19, 254-262 (2011). DOI: $10.1007 / \mathrm{s} 10924-010-0276-\mathrm{y}$
[35] Akçaözoğlu S., Ulu C.: Recycling of waste PET granules as aggregate in alkali-activated blast furnace slag/ metakaolin blends. Construction and Building Materials, 58, 31-37 (2014). DOI: 10.1016/j.conbuildmat.2014.02.011

[36] Albano C., Camacho N., Hernández M., Matheus A., Gutiérrez A.: Influence of high temperatures on PETconcrete properties. Macromolecular Symposia, 286, 195-202 (2009).

DOI: $10.1002 /$ masy.200951224

[37] Albano C., Camacho N., Hernández M., Matheus A., Gutiérrez A.: Influence of content and particle size of waste pet bottles on concrete behavior at different $w / c$ ratios. Waste Management, 29, 2707-2716 (2009).

DOI: 10.1016/j.wasman.2009.05.007

[38] Choi W-C., Yun H-D., Kang J-W., Kim S-W.: Development of recycled strain-hardening cement-based composite (SHCC) for sustainable infrastructures. Composites Part B: Engineering, 43, 627-635 (2012).

DOI: 10.1016/j.compositesb.2011.11.060

[39] Choi Y. W., Moon D. J., Kim Y. J., Lachemi M.: Characteristics of mortar and concrete containing fine aggregate manufactured from recycled waste polyethylene terephthalate bottles. Construction and Building Materials, 23, 2829-2835 (2009).

DOI: $10.1016 /$ j.conbuildmat.2009.02.036

[40] da Silva A. M., de Brito J., Veiga R.: Incorporation of fine plastic aggregates in rendering mortars. Construction and Building Materials, 71, 226-236 (2014). DOI: $10.1016 /$ j.conbuildmat.2014.08.026

[41] Foti D., Paparella F.: Impact behavior of structural elements in concrete reinforced with PET grids. Mechanics Research Communications, 57, 57-66 (2014). DOI: 10.1016/j.mechrescom.2014.02.007

[42] Fraternali F., Spadea S., Berardi V. P.: Effects of recycled PET fibres on the mechanical properties and seawater curing of Portland cement-based concretes. Construction and Building Materials, 61, 293-302 (2014). DOI: 10.1016/j.conbuildmat.2014.03.019

[43] Frigione M.: Recycling of PET bottles as fine aggregate in concrete. Waste Management, 30, 1101-1106 (2010). DOI: $10.1016 /$ j.wasman.2010.01.030

[44] Ge Z., Sun R., Zhang K., Gao Z., Li P.: Physical and mechanical properties of mortar using waste polyethylene terephthalate bottles. Construction and Building Materials, 44, 81-86 (2013).

DOI: 10.1016/j.conbuildmat.2013.02.073

[45] Hannawi K., Kamali-Bernard S., Prince W.: Physical and mechanical properties of mortars containing PET and PC waste aggregates. Waste Management, 30, 2312-2320 (2010).

DOI: $10.1016 /$ j.wasman.2010.03.028

[46] Hannawi K., Prince W., Kamali-Bernard S.: Effect of thermoplastic aggregates incorporation on physical, mechanical and transfer behaviour of cementitious materials. Waste and Biomass Valorization, 1, 251-259 (2010).

DOI: $10.1007 / \mathrm{s} 12649-010-9021-\mathrm{y}$ 
[47] Jang S-J., Rokugo K., Park W-S., Yun H-D.: Influence of rapid freeze-thaw cycling on the mechanical properties of sustainable strain-hardening cement composite (2SHCC). Materials, 7, 1422-1440 (2014). DOI: $10.3390 / \mathrm{ma} 7021422$

[48] Jo B-W., Park S-K., Park J-C.: Mechanical properties of polymer concrete made with recycled PET and recycled concrete aggregates. Construction and Building Materials, 22, 2281-2291 (2008).

DOI: $10.1016 /$ j.conbuildmat.2007.10.009

[49] Kim J-H. J., Park C-G., Lee S-W., Lee S-W., Won J-P.: Effects of the geometry of recycled PET fiber reinforcement on shrinkage cracking of cement-based composites. Composites Part B: Engineering, 39, 442-450 (2008). DOI: 10.1016/j.compositesb.2007.05.001

[50] Kim S. B., Yi N. H., Kim H. Y., Kim J-H. J., Song YC.: Material and structural performance evaluation of recycled PET fiber reinforced concrete. Cement and Concrete Composites, 32, 232-240 (2010). DOI: 10.1016/j.cemconcomp.2009.11.002

[51] Mahdi F., Abbas H., Khan A. A.: Flexural, shear and bond strength of polymer concrete utilizing recycled resin obtained from post consumer PET bottles. Construction and Building Materials, 44, 798-811 (2013). DOI: $10.1016 /$ j.conbuildmat.2013.03.081

[52] Marzouk O. Y., Dheilly R. M., Queneudec M.: Valorization of post-consumer waste plastic in cementitious concrete composites. Waste Management, 27, 310-318 (2007).

DOI: 10.1016/j.wasman.2006.03.012

[53] Vidales J. M. M., Hernández L. N., López J. I. T., Flores E. E. M., Hernández L. S.: Polymer mortars prepared using a polymeric resin and particles obtained from waste pet bottle. Construction and Building Materials, 65, 376-383 (2014).

DOI: $10.1016 /$ j.conbuildmat.2014.04.114

[54] Rebeiz K. S.: Strength and durability properties of polyester concrete using pet and fly ash wastes. Advanced Performance Materials, 3, 205-214 (1995). DOI: $10.1007 / \mathrm{BF} 00136746$

[55] Rebeiz K. S., Fowler D. W., Paul D. R.: Polymer concrete and polymer mortar using resins based on recycled poly(ethylene terephthalate). Journal of Applied Polymer Science, 44, 1649-1655 (1992). DOI: 10.1002/app.1992.070440919

[56] Reis J. M. L., Carneiro E. P.: Evaluation of PET waste aggregates in polymer mortars. Construction and Building Materials, 27, 107-111 (2012).

DOI: $10.1016 /$ j.conbuildmat.2011.08.020

[57] Reis J. M. L., Chianelli-Junior R., Cardoso J. L., Marinho F. J. V.: Effect of recycled PET in the fracture mechanics of polymer mortar. Construction and Building Materials, 25, 2799-2804 (2011). DOI: $10.1016 / \mathrm{j}$. conbuildmat.2010.12.056
[58] Reis J. M. L., Jurumenha M. A. G.: Investigation on the effects of polymer impregnated aggregate on polymer mortars properties. Materials and Structures, 46, 1383-1388 (2013). DOI: $10.1617 / \mathrm{s} 11527-012-9980-5$

[59] Safi B., Saidi M., Aboutaleb D., Maallem M.: The use of plastic waste as fine aggregate in the self-compacting mortars: Effect on physical and mechanical properties. Construction and Building Materials, 43, 436-442 (2013).

DOI: 10.1016/j.conbuildmat.2013.02.049

[60] Saikia N., de Brito J.: Mechanical properties and abrasion behaviour of concrete containing shredded PET bottle waste as a partial substitution of natural aggregate. Construction and Building Materials, 52, 236-244 (2014).

DOI: 10.1016/j.conbuildmat.2013.11.049

[61] Sikalidis C. A., Zabaniotou A. A., Famellos S. P.: Utilisation of municipal solid wastes for mortar production. Resources, Conservation and Recycling, 36, 155-167 (2002). DOI: $10.1016 / \mathrm{S} 0921-3449(02) 00018-6$

[62] Silva R. V., de Brito J., Saikia N.: Influence of curing conditions on the durability-related performance of concrete made with selected plastic waste aggregates. Cement and Concrete Composites, 35, 23-31 (2013). DOI: $10.1016 /$ j.cemconcomp.2012.08.017

[63] Won J-P., Jang C.-I., Lee S-W., Lee S-J., Kim H-Y.: Long-term performance of recycled PET fibre-reinforced cement composites. Construction and Building Materials, 24, 660-665 (2010).

DOI: 10.1016/j.conbuildmat.2009.11.003

[64] Dębska B., Lichołai L.: A study of the effect of corrosive solutions on selected physical properties of modified epoxy mortars. Construction and Building Materials, 65, 604-611 (2014).

DOI: $10.1016 /$ j.conbuildmat.2014.05.038

[65] de Mello D., Pezzin S. H., Amico S. C.: The effect of post-consumer PET particles on the performance of flexible polyurethane foams. Polymer Testing, 28, 702-708 (2009).

DOI: 10.1016/j.polymertesting.2009.05.014

[66] Altun S., Ulcay Y.: Improvement of waste recycling in PET fiber production. Journal of Polymers and the Environment, 12, 231-237 (2004). DOI: $10.1007 / \mathrm{s} 10924-004-8150-4$

[67] Assadi R., Colin X., Verdu J.: Irreversible structural changes during PET recycling by extrusion. Polymer, 45, 4403-4412 (2004). DOI: $10.1016 /$ j.polymer.2004.04.029

[68] Frounchi M.: Studies on degradation of PET in mechanical recycling. Macromolecular Symposia, 144, 465-469 (1999).

DOI: $10.1002 /$ masy. 19991440142 
[69] Badia J. D., Strömberg E., Karlsson S., Ribes-Greus A.: The role of crystalline, mobile amorphous and rigid amorphous fractions in the performance of recycled poly (ethylene terephthalate) (PET). Polymer Degradation and Stability, 97, 98-107 (2012).

DOI: $10.1016 /$ j.polymdegradstab.2011.10.008

[70] Badía J. D., Strömberg E., Ribes-Greus A., Karlsson S.: A statistical design of experiments for optimizing the MALDI-TOF-MS sample preparation of polymers. An application in the assessment of the thermo-mechanical degradation mechanisms of poly (ethylene terephthalate). Analytica Chimica Acta, 692, 85-95 (2011). DOI: $10.1016 /$ j.aca.2011.02.063

[71] Badía J. D., Vilaplana F., Karlsson S., Ribes-Greus A.: Thermal analysis as a quality tool for assessing the influence of thermo-mechanical degradation on recycled poly(ethylene terephthalate). Polymer Testing, 28, 169175 (2009).

DOI: $10.1016 /$ j.polymertesting.2008.11.010

[72] del Mar Castro López M., Pernas A. I. A., López M. J. A., Latorre A. L., Vilariño J. M. L., Rodríguez M. V. G.: Assessing changes on poly(ethylene terephthalate) properties after recycling: Mechanical recycling in laboratory versus postconsumer recycled material. Materials Chemistry and Physics, 147, 884-894 (2014).

DOI: 10.1016/j.matchemphys.2014.06.034

[73] Dias M. L., Nascimento C. R.: Thermal properties of post-consumer pet processed in presence of phosphites. Journal of Thermal Analysis and Calorimetry, 69, 551559 (2002).

DOI: $10.1023 / \mathrm{A}: 1019963923884$

[74] Paci M., La Mantia F. P.: Competition between degradation and chain extension during processing of reclaimed poly(ethylene terephthalate). Polymer Degradation and Stability, 61, 417-420 (1998).

DOI: 10.1016/S0141-3910(97)00227-9

[75] Paci M., La Mantia F. P.: Influence of small amounts of polyvinylchloride on the recycling of polyethyleneterephthalate. Polymer Degradation and Stability, 63, 11-14 (1999).

DOI: 10.1016/S0141-3910(98)00053-6

[76] Cruz S. A., Zanin M.: PET recycling: Evaluation of the solid state polymerization process. Journal of Applied Polymer Science, 99, 2117-2123 (2006). DOI: 10.1002/app.22526

[77] Koo H. J., Chang G. S., Kim S. H., Hahm W. G., Park S. Y.: Effects of recycling processes on physical, mechanical and degradation properties of PET yarns. Fibers and Polymers, 14, 2083-2087 (2013).

DOI: $10.1007 / \mathrm{s} 12221-013-2083-2$

[78] Holtman K. M., Kodama A., Klamczynski A. P., Flynn A., Bozzi D. V., Torres L., Franqui-Villanueva D., Mao J., Glenn G. M., Orts W. J.: Thermal properties of poly (ethylene terephthalate) recovered from municipal solid waste by steam autoclaving. Journal of Applied Polymer Science, 126, 1698-1708 (2012).

DOI: $10.1002 / a p p .36752$
[79] Holland Colours: Holland's additives mask recycled appearance in PET. Additives for Polymers, 2, 1-2 (2004).

DOI: 10.1016/S0306-3747(04)00049-1

[80] Kaneka: Modifiers spur growth in PET recycling. Plastics, Additives and Compounding, 7, 32-33 (2005).

DOI: 10.1016/S1464-391X(05)70430-X

[81] Hamzehlou S., Katbab A. A.: Bottle-to-bottle recycling of pet via nanostructure formation by melt intercalation in twin screw compounder: Improved thermal, barrier, and microbiological properties. Journal of Applied Polymer Science, 106, 1375-1382 (2007).

DOI: $10.1002 / a p p .26730$

[82] Cheng H., Tian M., Zhang L.: Toughening of recycled poly(ethylene terephthalate)/glass fiber blends with ethylene-butyl acrylate-glycidyl methacrylate copolymer and maleic anhydride grafted polyethylene-octene rubber. Journal of Applied Polymer Science, 109, 27952801 (2008).

DOI: 10.1002/app.27564

[83] Abdel Tawab K., Ibrahim S. M., Magida M. M.: The effect of gamma irradiation on mechanical, and thermal properties of recycling polyethylene terephthalate and low density polyethylene (r-PET/LDPE) blend compatibilized by ethylene vinyl acetate (EVA). Journal of Radioanalytical and Nuclear Chemistry, 295, 1313-1319 (2013).

DOI: $10.1007 / \mathrm{s} 10967-012-2163-6$

[84] Raffa P., Coltelli M-B., Castelvetro V.: Expanding the application field of post-consumer poly(ethylene terephthalate) through structural modification by reactive blending. Journal of Applied Polymer Science, 131, 40881/1-40881/11 (2014).

DOI: $10.1002 / a p p .40881$

[85] Zhang Y., Zhang H., Yu Y., Guo W., Wu C.: Recycled poly(ethylene terephthalate)/linear low-density polyethylene blends through physical processing. Journal of Applied Polymer Science, 114, 1187-1194 (2009). DOI: $10.1002 /$ app.30030

[86] Aminuddin S. F., Wei L. Y., Hamada H., Adnan N.: Recycled poly(ethylene terephthalate)/recycled polypropylene blend: Effect of hygrothermal treatment. in 'IEEE Symposium on Humanities, Science and Engineering Research, SHUSER 2012, Kuala Lumpur, Malaysia' 239-244 (2012).

DOI: 10.1109/SHUSER.2012.6268857

[87] Ávila A. F., Duarte M. V.: A mechanical analysis on recycled PET/HDPE composites. Polymer Degradation and Stability, 80, 373-382 (2003). DOI: 10.1016/S0141-3910(03)00025-9

[88] Ávila A. F., Rodrigues P. C. M., Santos D. B., Faria A. C. A.: A dual analysis for recycled particulate composites: Linking micro- and macro-mechanics. Materials Characterization, 50, 281-291 (2003). DOI: $10.1016 / \mathrm{S} 1044-5803(03) 00124-4$ 
[89] Ávila A. F., Jabbur F. G.: Sheet forming studies using low-cost composites. Journal of Thermoplastic Composite Materials, 18, 5-22 (2005).

DOI: $\underline{10.1177 / 0892705705041158}$

[90] Evstatiev M., Fakirov S., Krasteva B., Friedrich K., Covas J. A., Cunha A. M.: Recycling of poly(ethylene terephthalate) as polymer-polymer composites. Polymer Engineering and Science, 42, 826-835 (2002).

DOI: 10.1002/pen.10994

[91] Kayaisang S., Amornsakchai T., Saikrasun S.: Potential utilization of recycled PET in comparison with liquid crystalline polymer as an additive for HDPE based composite fibers: Comparative investigation on mechanical performance of cross-ply laminates. Journal of Polymer Engineering, 33, 793-802 (2013).

DOI: $10.1515 /$ polyeng-2013-0155

[92] Kayaisang S., Saikrasun S., Amornsakchai T.: Potential use of recycled PET in comparison with liquid crystalline polyester as a dual functional additive for enhancing heat stability and reinforcement for high density polyethylene composite fibers. Journal of Polymers and the Environment, 21, 191-206 (2013).

DOI: $10.1007 / \mathrm{s} 10924-012-0446-1$

[93] Navarro R., Ferrándiz S., López J., Seguí V. J.: The influence of polyethylene in the mechanical recycling of polyethylene terephtalate. Journal of Materials Processing Technology, 195, 110-116 (2008).

DOI: $10.1016 /$ j.jmatprotec.2007.04.126

[94] Oromiehie A., Mamizadeh A.: Recycling PET beverage bottles and improving properties. Polymer International, 53, 728-732 (2004).

DOI: $10.1002 /$ pi.1389

[95] Geyer B., Röhner S., Lorenz G., Kandelbauer A.: Designing oligomeric ethylene terephtalate building blocks by chemical recycling of polyethylene terephtalate. Journal of Applied Polymer Science, 131, 39786/1-39786/12 (2014).

DOI: $10.1002 / a p p .39786$

[96] Day M., Parfenov V., Wiles D. M.: Combustion and pyrolysis of poly(ethylene terephthalate). III. The effect of tris(2,3-dibromopropyl) phosphate on the products of pyrolysis. Journal of Applied Polymer Science, 27, 575-589 (1982).

DOI: 10.1002/app.1982.070270221

[97] Arena U., Mastellone M. L.: Defluidization phenomena during the pyrolysis of two plastic wastes. Chemical Engineering Science, 55, 2849-2860 (2000).

DOI: 10.1016/S0009-2509(99)00533-3

[98] Barriocanal C., Díez M. A., Alvarez R.: PET recycling for the modification of precursors in carbon materials manufacture. Journal of Analytical and Applied Pyrolysis, 73, 45-51 (2005).

DOI: $10.1016 /$ j.jaap.2004.10.002

[99] Chen C-H.: Study of glycolysis of poly(ethylene terephthalate) recycled from postconsumer soft-drink bottles. III. Further investigation. Journal of Applied Polymer Science, 87, 2004-2010 (2003).

DOI: 10.1002/app.11694
[100] Díez M. A., Alvarez R.: Advances in the recycling of plastic wastes for metallurgical coke production. Journal of Material Cycles and Waste Management, 15, 247255 (2013).

DOI: $10.1007 / \mathrm{s} 10163-012-0103-8$

[101] Díez M. A., Barriocanal C., Álvarez R.: Plastic wastes as modifiers of the thermoplasticity of coal. Energy and Fuels, 19, 2304-2316 (2005).

DOI: $10.1021 / \mathrm{ef0501041}$

[102] Brems A., Baeyens J., Beerlandt J., Dewil R.: Thermogravimetric pyrolysis of waste polyethylene-terephthalate and polystyrene: A critical assessment of kinetics modelling. Resources, Conservation and Recycling, 55, 772-781 (2011).

DOI: $10.1016 /$ j.resconrec.2011.03.003

[103] Brems A., Baeyens J., Vandecasteele C., Dewil R.: Polymeric cracking of waste polyethylene terephthalate to chemicals and energy. Journal of the Air and Waste Management Association, 61, 721-731 (2011). DOI: 10.3155/1047-3289.61.7.721

[104] Urbanová M., Šubrt J., Galíková A., Pola J.: IR laser ablative degradation of poly(ethylene terephthalate): Formation of insoluble films with differently bonded $\mathrm{C}=\mathrm{O}$ groups. Polymer Degradation and Stability, 91, 2318-2323 (2006).

DOI: 10.1016/j.polymdegradstab.2006.04.016

[105] Arenillas A., Rubiera F., Parra J. B., Ania C. O., Pis J. J.: Surface modification of low cost carbons for their application in the environmental protection. Applied Surface Science, 252, 619-624 (2005).

DOI: 10.1016/j.apsusc.2005.02.076

[106] Kongkarat S., Khanna R., Koshy P., O’Kane P., Sahajwalla V.: Recycling waste polymers in EAF steelmaking: Influence of polymer composition on carbon/slag interactions. ISIJ International, 52, 385-393 (2012). DOI: $10.2355 /$ isijinternational.52.385

[107] Nomura S., Kato K., Nakagawa T., Komaki I.: The effect of plastic addition on coal caking properties during carbonization. Fuel, 82, 1775-1782 (2003). DOI: 10.1016/S0016-2361(03)00120-0

[108] Parra J. B., Ania C. O., Arenillas A., Rubiera F., Pis J. J.: High value carbon materials from PET recycling. Applied Surface Science, 238, 304-308 (2004). DOI: 10.1016/j.apsusc.2004.05.229

[109] Sahajwalla V., Zaharia M., Kongkarat S., Khanna R., Rahman M., Saha-Chaudhury N., O'Kane P., Dicker J., Skidmore C., Knights D.: Recycling end-of-life polymers in an electric arc furnace steelmaking process: Fundamentals of polymer reactions with slag and metal. Energy and Fuels, 26, 58-66 (2012). DOI: $10.1021 / \mathrm{ef201175t}$

[110] Wei L., Yan N., Chen Q.: Converting poly(ethylene terephthalate) waste into carbon microspheres in a supercritical $\mathrm{CO}_{2}$ system. Environmental Science and Technology, 45, 534-539 (2011). DOI: $10.1021 / \mathrm{es} 102431 \mathrm{e}$ 
[111] Zhang F-S., Itoh H.: Adsorbents made from waste ashes and post-consumer PET and their potential utilization in wastewater treatment. Journal of Hazardous Materials, 101, 323-337 (2003). DOI: $10.1016 / \mathrm{S} 0304-3894(03) 00208-5$

[112] Scheirs J.: Recycling of PET. in 'Polymer recycling' (ed.: Scheirs J.) Wiley, Chichester 121-145 (1998).

[113] Burat F., Güney A., Olgaç Kangal M.: Selective separation of virgin and post-consumer polymers (PET and PVC) by flotation method. Waste Management, 29, 1807-1813 (2009).

DOI: $10.1016 /$ j.wasman.2008.12.018

[114] Carvalho M. T., Agante E., Durão F.: Recovery of PET from packaging plastics mixtures by wet shaking table. Waste Management, 27, 1747-1754 (2007). DOI: 10.1016/j.wasman.2006.08.015

[115] Carvalho T., Durão F., Ferreira C.: Separation of packaging plastics by froth flotation in a continuous pilot plant. Waste Management, 30, 2209-2215 (2010). DOI: $10.1016 /$ j.wasman.2010.05.023

[116] Dobrovszky K., Ronkay F.: Alternative polymer separation technology by centrifugal force in a melted state. Waste Management, 34, 2104-2112 (2014). DOI: 10.1016/j.wasman.2014.05.006

[117] Dodbiba G., Haruki N., Shibayama A., Miyazaki T., Fujita T.: Combination of sink-float separation and flotation technique for purification of shredded PETbottle from PE or PP flakes. International Journal of Mineral Processing, 65, 11-29 (2002).

DOI: $10.1016 / \mathrm{S} 0301-7516(01) 00056-4$

[118] Dodbiba G., Sadaki J., Okaya K., Shibayama A., Fujita T.: The use of air tabling and triboelectric separation for separating a mixture of three plastics. Minerals Engineering, 18, 1350-1360 (2005).

DOI: $10.1016 /$ j.mineng.2005.02.015

[119] Hori K., Tsunekawa M., Ueda M., Hiroyoshi N., Ito M., Okada H.: Development of a new gravity separator for plastics - A hybrid-jig -. Materials Transactions, 50, 2844-2847 (2009). DOI: $10.2320 /$ matertrans.M-M2009825

[120] Marques G. A., Tenório J. A. S.: Use of froth flotation to separate PVC/PET mixtures. Waste Management, 20, 265-269 (2000). DOI: $10.1016 / \mathrm{S} 0956-053 \mathrm{X}(99) 00333-5$

[121] Shen H., Forssberg E., Pugh R. J.: Selective flotation separation of plastics by chemical conditioning with methyl cellulose. Resources, Conservation and Recycling, 35, 229-241 (2002).

DOI: 10.1016/S0921-3449(02)00003-4

[122] Shen H., Pugh R. J., Forssberg E.: Floatability, selectivity and flotation separation of plastics by using a surfactant. Colloids and Surfaces A: Physicochemical and Engineering Aspects, 196, 63-70 (2002). DOI: 10.1016/S0927-7757(01)00706-3
[123] Tsunekawa M., Naoi B., Ogawa S., Hori K., Hiroyoshi N., Ito M., Hirajima T.: Jig separation of plastics from scrapped copy machines. International Journal of Mineral Processing, 76, 67-74 (2005).

DOI: $10.1016 /$ j.minpro.2004.12.001

[124] Zou Y., Hsieh J. S., Mehnert E., Kokoszka J.: The study of PET recyclable polymers as paper coatings. Progress in Organic Coatings, 60, 127-131 (2007).

DOI: $10.1016 /$ j.porgcoat.2007.07.012

[125] Adams C. J., Earle M. J., Seddon K. R.: Catalytic cracking reactions of polyethylene to light alkanes in ionic liquids. Green Chemistry, 2, 21-24 (2000). DOI: 10.1039/A908167D

[126] Wang H., Li Z., Liu Y., Zhang X., Zhang S.: Degradation of poly(ethylene terephthalate) using ionic liquids. Green Chemistry, 11, 1568-1575 (2009).

DOI: $10.1039 / \mathrm{b} 906831 \mathrm{~g}$

[127] Kržan A.: Poly(ethylene terephthalate) glycolysis under microwave irradiation. Polymers for Advanced Technologies, 10, 603-606 (1999).

DOI: 10.1002/(SICI)1099-1581(199910)10:10<603:: AID-PAT914>3.0.CO;2-V

[128] Beneš H., Slabá J., Walterová Z., Rais D.: Recycling of waste poly(ethylene terephthalate) with castor oil using microwave heating. Polymer Degradation and Stability, 98, 2232-2243 (2013).

DOI: $10.1016 /$ j.polymdegradstab.2013.08.019

[129] Tokiwa Y., Suzuki T.: Hydrolysis of polyesters by lipases. Nature, 270, 76-78 (1977).

DOI: $10.1038 / 270076 \mathrm{a} 0$

[130] Kawai F., Oda M., Tamashiro T., Waku T., Tanaka N., Yamamoto M., Mizushima H., Miyakawa T., Tanokura M.: A novel $\mathrm{Ca}^{2+}$-activated, thermostabilized polyesterase capable of hydrolyzing polyethylene terephthalate from saccharomonospora viridis AHK190. Applied Microbiology and Biotechnology, 98, 1005310064 (2014).

DOI: $10.1007 / \mathrm{s} 00253-014-5860-\mathrm{y}$

[131] Mueller R-J.: Biological degradation of synthetic polyesters - Enzymes as potential catalysts for polyester recycling. Process Biochemistry, 41, 2124-2128 (2006).

DOI: $10.1016 /$ j.procbio.2006.05.018

[132] Donelli I., Freddi G., Nierstrasz V. A., Taddei P.: Surface structure and properties of poly-(ethylene terephthalate) hydrolyzed by alkali and cutinase. Polymer Degradation and Stability, 95, 1542-1550 (2010). DOI: $10.1016 /$ j.polymdegradstab.2010.06.011

[133] Zhang J., Wang X., Gong J., Gu Z.: A study on the biodegradability of polyethylene terephthalate fiber and diethylene glycol terephthalate. Journal of Applied Polymer Science, 93, 1089-1096 (2004).

DOI: $10.1002 /$ app.20556

[134] Wang J., Xue L., Wang W., Jiao S.: Synthesis of diisooctyl terephthalate (DOTP) plasticizer (in Chinese). Huaxue Shijie, 32, 208-210 (1991). 
[135] Fávaro S. L., Freitas A. R., Ganzerli T. A., Pereira A. G. B., Cardozo A. L., Baron O., Muniz E. C., Girotto E. M., Radovanovic E.: PET and aluminum recycling from multilayer food packaging using supercritical ethanol. Journal of Supercritical Fluids, 75, 138-143 (2013).

DOI: 10.1016/j.supflu.2012.12.015

[136] Liu S., Wang Z., Li L., Yu S., Xie C., Liu F.: Butanol alcoholysis reaction of polyethylene terephthalate using acidic ionic liquid as catalyst. Journal of Applied Polymer Science, 130, 1840-1844 (2013).

DOI: 10.1002/APP.39246

[137] Nikje M. M. A., Nazari F.: Microwave-assisted depolymerization of poly(ethylene terephthalate) [PET] at atmospheric pressure. Advances in Polymer Technology, 25, 242-246 (2006).

DOI: $10.1002 / \mathrm{adv} .20080$

[138] Dutt K., Soni R. K.: Synthesis and characterization of polymeric plasticizer from PET waste and its applications in nitrile rubber and nitrile-PVC blend. Iranian Polymer Journal, 22, 481-491 (2013).

DOI: $10.1007 / \mathrm{s} 13726-013-0148-0$

[139] Chabert M., Bounor-Legaré V., Mignard N., Cassagnau P., Chamignon C., Boisson F.: Formation of new alkyl functionalized poly(ethylene terephthalate) oligomers through exchange reactions with titanium alkoxides in melt conditions. Polymer Degradation and Stability, 102, 122-131 (2014).

DOI: $10.1016 /$ j.polymdegradstab.2014.01.030

[140] Siggel E., Heisenberg E., Lotz R.: Regeneration of terephthalic acid dimethyl ester from polyethylene terephthalate. U.S. Patent 3037050, USA (1962).

[141] Genta M., Iwaya T., Sasaki M., Goto M.: Supercritical methanol for polyethylene terephthalate depolymerization: Observation using simulator. Waste Management, 27, 1167-1177 (2007).

DOI: 10.1016/j.wasman.2006.06.005

[142] Genta M., Iwaya T., Sasaki M., Goto M., Hirose T.: Depolymerization mechanism of poly(ethylene terephthalate) in supercritical methanol. Industrial and Engineering Chemistry Research, 44, 3894-3900 (2005). DOI: $10.1021 / \mathrm{ie} 0488187$

[143] Goto M.: Chemical recycling of plastics using suband supercritical fluids. The Journal of Supercritical Fluids, 47, 500-507 (2009).

DOI: $10.1016 /$ j.supflu.2008.10.011

[144] Goto M., Koyamoto H., Kodama A., Hirose T., Nagaoka S.: Depolymerization of polyethylene terephthalate in supercritical methanol. Journal of Physics: Condensed Matter, 14, 11427-11430 (2002). DOI: $10.1088 / 0953-8984 / 14 / 44 / 494$

[145] Goto M., Koyamoto H., Kodama A., Hirose T., Nagaoka S., McCoy B. J.: Degradation kinetics of polyethylene terephthalate in supercritical methanol. AIChE Journal, 48, 136-144 (2002). DOI: $10.1002 /$ aic.690480114
[146] Kurokawa H., Ohshima M-A., Sugiyama K., Miura H.: Methanolysis of polyethylene terephthalate (PET) in the presence of aluminium tiisopropoxide catalyst to form dimethyl terephthalate and ethylene glycol. Polymer Degradation and Stability, 79, 529-533 (2003).

DOI: 10.1016/S0141-3910(02)00370-1

[147] Siddiqui M. N., Redhwi H. H., Achilias D. S.: Recycling of poly(ethylene terephthalate) waste through methanolic pyrolysis in a microwave reactor. Journal of Analytical and Applied Pyrolysis, 98, 214-220 (2012). DOI: 10.1016/j.jaap.2012.09.007

[148] Yang Y., Lu Y., Xiang H., Xu Y., Li Y.: Study on methanolytic depolymerization of PET with supercritical methanol for chemical recycling. Polymer Degradation and Stability, 75, 185-191 (2002).

DOI: 10.1016/S0141-3910(01)00217-8

[149] Güçlü G., Yalçinyuva T., Özgümüş S., Orbay M.: Hydrolysis of waste polyethylene terephthalate and characterization of products by differential scanning calorimetry. Thermochimica Acta, 404, 193-205 (2003).

DOI: 10.1016/S0040-6031(03)00160-6

[150] Zhang L.: Kinetics of hydrolysis of poly(ethylene terephthalate) wastes catalyzed by dual functional phase transfer catalyst: A mechanism of chain-end scission. European Polymer Journal, 60, 1-5 (2014). DOI: $10.1016 /$ j.eurpolymj.2014.08.007

[151] Kazarian S. G., Martirosyan G. G.: ATR-IR spectroscopy of superheated water and in situ study of the hydrothermal decomposition of poly(ethylene terephthalate). Physical Chemistry Chemical Physics, 4, 3759-3763 (2002).

DOI: $10.1039 / \mathrm{b} 202119 \mathrm{f}$

[152] Liu Y., Wang M., Pan Z.: Catalytic depolymerization of polyethylene terephthalate in hot compressed water. The Journal of Supercritical Fluids, 62, 226-231 (2012). DOI: 10.1016/j.supflu.2011.11.001

[153] Noritake A., Hori M., Shigematsu M., Tanahashi M.: Recycling of polyethylene terephthalate using highpressure steam treatment. Polymer Journal, 40, 498502 (2008).

DOI: $10.1295 /$ polymj.PJ2007237

[154] Sato O., Arai K., Shirai M.: Hydrolysis of poly(ethylene terephthalate) and poly(ethylene 2,6-naphthalene dicarboxylate) using water at high temperature: Effect of proton on low ethylene glycol yield. Catalysis Today, 111, 297-301 (2006). DOI: $10.1016 /$ j.cattod.2005.10.040

[155] Mancini S. D., Nogueira A. R., Rangel E. C., da Cruz N. C.: Solid-state hydrolysis of postconsumer polyethylene terephthalate after plasma treatment. Journal of Applied Polymer Science, 127, 1989-1996 (2013). DOI: 10.1002/app.37591 
[156] Sharma V., Parashar P., Srivastava P., Kumar S., Agarwal D. D., Richharia N.: Recycling of waste PET-bottles using dimethyl sulfoxide and hydrotalcite catalyst. Journal of Applied Polymer Science, 129, 1513-1519 (2013).

DOI: 10.1002/app.38829

[157] Siddiqui M. N., Achilias D. S., Redhwi H. H., Bikiaris D. N., Katsogiannis K. G., Karayannidis G. P.: Hydrolytic depolymerization of PET in a microwave reactor. Macromolecular Materials and Engineering, 295, 575584 (2010). DOI: $10.1002 / \mathrm{mame} .201000050$

[158] Zope V. S., Mishra S.: Kinetics of neutral hydrolytic depolymerization of PET (polyethylene terephthalate) waste at higher temperature and autogenious pressures. Journal of Applied Polymer Science, 110, 2179-2183 (2008). DOI: $10.1002 / a p p .28190$

[159] de Carvalho G. M., Muniz E. C., Rubira A. F.: Hydrolysis of post-consume poly(ethylene terephthalate) with sulfuric acid and product characterization by WAXD, ${ }^{13} \mathrm{C}$ NMR and DSC. Polymer Degradation and Stability, 91, 1326-1332 (2006).

DOI: $10.1016 /$ j.polymdegradstab.2005.08.005

[160] Kumar A., Rao T. R.: Kinetics of hydrolysis of polyethylene terephthalate pellets in nitric acid. Journal of Applied Polymer Science, 87, 1781-1785 (2003). DOI: 10.1002/app.11579

[161] Yoshioka T., Sato T., Okuwaki A.: Hydrolysis of waste PET by sulfuric acid at $150^{\circ} \mathrm{C}$ for a chemical recycling. Journal of Applied Polymer Science, 52, 13531355 (1994). DOI: 10.1002/app.1994.070520919

[162] Caparanga A. R., Basilia B. A., Dagbay K. B., Salvacion J. W. L.: Factors affecting degradation of polyethylene terephthalate (PET) during pre-flotation conditioning. Waste Management, 29, 2425-2428 (2009). DOI: $10.1016 /$ j.wasman.2009.03.025

[163] Karayannidis G. P., Chatziavgoustis A. P., Achilias D. S.: Poly(ethylene terephthalate) recycling and recovery of pure terephthalic acid by alkaline hydrolysis. Advances in Polymer Technology, 21, 250-259 (2002). DOI: $10.1002 / \mathrm{adv} .10029$

[164] Khalaf H. I., Hasan O. A.: Effect of quaternary ammonium salt as a phase transfer catalyst for the microwave depolymerization of polyethylene terephthalate waste bottles. Chemical Engineering Journal, 192, 4548 (2012).

DOI: $10.1016 /$ j.cej.2012.03.081

[165] Kosmidis V. A., Achilias D. S., Karayannidis G. P.: Poly(ethylene terephthalate) recycling and recovery of pure terephthalic acid. Kinetics of a phase transfer catalyzed alkaline hydrolysis. Macromolecular Materials and Engineering, 286, 640-647 (2001).

DOI: 10.1002/1439-2054(20011001)286:10<640::AIDMAME640>3.0.CO;2-1
[166] Mishra S., Zope V. S., Goje A. S.: Kinetic and thermodynamic studies of depolymerisation of poly(ethylene terephthalate) by saponification reaction. Polymer International, 51, 1310-1315 (2002).

DOI: $10.1002 /$ pi.873

[167] Paliwal N. R., Mungray A. K.: Ultrasound assisted alkaline hydrolysis of poly(ethylene terephthalate) in presence of phase transfer catalyst. Polymer Degradation and Stability, 98, 2094-2101 (2013).

DOI: $10.1016 /$ j.polymdegradstab.2013.06.030

[168] Shafique U., Zaman W. U., Anwar J., Munawar M. A., Salman M., Dar A., Rehman R., Ashraf U., Ahmad S.: A rapid, economical, and eco-friendly method to recycle terephthalic acid from waste poly (ethylene terphthalate) bottles. International Journal of Polymeric Materials and Polymeric Biomaterials, 60, 1147-1151 (2011).

DOI: $10.1080 / 00914037.2011 .557802$

[169] Rosmaninho M. G., Jardim E., Moura F. C. C., Ferreira G. L., Thom V., Yoshida M. I., Araujo M. H., Lago R. M.: Surface hydrolysis of postconsumer polyethylene terephthalate to produce adsorbents for cationic contaminants. Journal of Applied Polymer Science, 102, 5284-5291 (2006).

DOI: $10.1002 / a p p .24790$

[170] Karayannidis G. P., Achilias D. S.: Chemical recycling of poly(ethylene terephthalate). Macromolecular Materials and Engineering, 292, 128-146 (2007),

DOI: $10.1002 /$ mame.200600341

[171] Kao C-Y., Cheng W-H., Wan B-Z.: Investigation of alkaline hydrolysis of polyethylene terephthalate by differential scanning calorimetry and thermogravimetric analysis. Journal of Applied Polymer Science, 70, 1939-1945 (1998).

DOI: $10.1002 /(\mathrm{SICI}) 1097-4628(19981205) 70: 10<1939$ $\because$ AID-APP8>3.0.CO;2-G

[172] Pingale N. D., Shukla S. R.: Microwave assisted ecofriendly recycling of poly (ethylene terephthalate) bottle waste. European Polymer Journal, 44, 4151-4156 (2008).

DOI: 10.1016/j.eurpolymj.2008.09.019

[173] Roy P. K, Mathur R., Kumar D., Rajagopal C.: Tertiary recycling of poly(ethylene terephthalate) wastes for production of polyurethane-polyisocyanurate foams. Journal of Environmental Chemical Engineering, 1, 1062-1069 (2013).

DOI: $10.1016 /$ j.jece.2013.08.019

[174] Colomines G., van der Lee A., Robin J-J., Boutevin B.: $\mathrm{X}$-ray diffraction of the crystallinity of glycolysates derived from PET. European Polymer Journal, 44, 2874-2885 (2008).

DOI: 10.1016/j.eurpolymj.2008.07.008

[175] El Mejjatti A., Harit T., Riahi A., Khiari R., Bouabdallah I., Malek F.: Chemical recycling of poly(ethylene terephthalate). Application to the synthesis of multiblock copolyesters. Express Polymer Letters, 8, 544553 (2014).

DOI: $\underline{10.3144 / \text { expresspolymlett.2014.58 }}$ 
[176] El-Sherbiny S. I., Morsy F. A., Atta A. M.: Synthesis of new cationic surfactants based on recycled poly(ethylene terephthalate) for deinking of solvent-based ink from low-density polyethylene surface. Journal of Applied Polymer Science, 118, 1160-1172 (2010). DOI: 10.1002/app.32488

[177] Farahat M. S.: Mechanical characteristics of modified unsaturated polyester resins derived from poly(ethylene terephthalate) waste. Polymer International, 51, 183-189 (2002).

DOI: $10.1002 /$ pi. 818

[178] Farahat M. S., Nikles D. E.: On the UV Curability and mechanical properties of novel binder systems derived from poly(ethylene terephthalate) (PET) waste for solventless magnetic tape manufacturing, 2 . Methacrylated oligoesters. Macromolecular Materials and Engineering, 287, 353-362 (2002).

DOI: 10.1002/1439-2054(20020501)287:5<353::AIDMAME353>3.0.CO;2-H

[179] Karayannidis G. P., Achilias D. S., Sideridou I. D., Bikiaris D. N.: Alkyd resins derived from glycolized waste poly(ethylene terephthalate). European Polymer Journal, 41, 201-210 (2005).

DOI: 10.1016/j.eurpolymj.2004.10.001

[180] Barboza E. S., Lopez D. R., Amico S. C., Ferreira C. A.: Determination of a recyclability index for the PET glycolysis. Resources, Conservation and Recycling, 53, 122-128 (2009).

DOI: $10.1016 /$ j.resconrec.2008.10.002

[181] Abdelaal M. Y., Sobahi T. R., Makki M. S. I.: Chemical transformation of pet waste through glycolysis. Construction and Building Materials, 25, 3267-3271 (2011).

DOI: 10.1016/j.conbuildmat.2011.03.013

[182] Kathalewar M., Dhopatkar N., Pacharane B., Sabnis A., Raut P., Bhave V.: Chemical recycling of PET using neopentyl glycol: Reaction kinetics and preparation of polyurethane coatings. Progress in Organic Coatings, 76, 147-156 (2013).

DOI: $10.1016 /$ j.porgcoat.2012.08.023

[183] Abdullah N. M., Ahmad I.: Potential of using polyester reinforced coconut fiber composites derived from recycling polyethylene terephthalate (PET) waste. Fibers and Polymers, 14, 584-590 (2013). DOI: $10.1007 / \mathrm{s} 12221-013-0584-7$

[184] Baliga S., Wong W. T.: Depolymerization of poly(ethylene terephthalate) recycled from post-consumer softdrink bottles. Journal of Polymer Science Part A: Polymer Chemistry, 27, 2071-2082 (1989). DOI: $10.1002 /$ pola.1989.080270625

[185] Pimpan V., Sirisook R., Chuayjuljit S.: Synthesis of unsaturated polyester resin from postconsumer PET bottles: Effect of type of glycol on characteristics of unsaturated polyester resin. Journal of Applied Polymer Science, 88, 788-792 (2003).

DOI: $\underline{10.1002 / a p p .11567}$
[186] Puangsansuk K., Opaprakasit M., Udomkichdecha W., Potiyaraj P.: Effects of saturated acids on physical properties of UPE resins prepared from recycled PET products. Journal of Polymers and the Environment, 17, 65-70 (2009).

DOI: 10.1007/s10924-009-0122-2

[187] Shukla S. R., Harad A. M., Jawale L. S.: Recycling of waste PET into useful textile auxiliaries. Waste Management, 28, 51-56 (2008).

DOI: $10.1016 /$ j.wasman.2006.11.002

[188] Shukla S. R., Harad A. M., Jawale L. S.: Chemical recycling of PET waste into hydrophobic textile dyestuffs. Polymer Degradation and Stability, 94, 604609 (2009).

DOI: 10.1016/j.polymdegradstab.2009.01.007

[189] Shukla S. R., Kulkarni K. S.: Depolymerization of poly (ethylene terephthalate) waste. Journal of Applied Polymer Science, 85, 1765-1770 (2002).

DOI: 10.1002/app.10714

[190] Essawy H. A., Tawfik M. E., Elsayed N. H.: Effect of addition of glycolysis products of poly(ethyleneterephthalate) wastes to urea-formaldehyde resin on its adhesion performance to wood substrates and formaldehyde emission. Journal of Applied Polymer Science, 123, 2377-2383 (2012).

DOI: 10.1002/app.34750

[191] Pingale N. D., Palekar V. S., Shukla S. R.: Glycolysis of postconsumer polyethylene terephthalate waste. Journal of Applied Polymer Science, 115, 249-254 (2010).

DOI: 10.1002/app.31092

[192] Ghaemy M., Mossaddegh K.: Depolymerisation of poly(ethylene terephthalate) fibre wastes using ethylene glycol. Polymer Degradation and Stability, 90, 570-576 (2005).

DOI: 10.1016/j.polymdegradstab.2005.03.011

[193] Carné Sánchez A., Collinson S. R.: The selective recycling of mixed plastic waste of polylactic acid and polyethylene terephthalate by control of process conditions. European Polymer Journal, 47, 1970-1976 (2011).

DOI: $10.1016 /$ j.eurpolymj.2011.07.013

[194] Maeda Y., Mori H., Maeda T., Itoh O., Yamaguchi K., Kubota S., Nakayama A., Kawasaki N., Yamamoto N., Aiba S.: Characterization of novel biodegradable copolyesters prepared from glycolyzed products of poly(ethylene terephthalate). Journal of Applied Polymer Science, 84, 1838-1847 (2002).

DOI: 10.1002/app.10462

[195] Al-Sabagh A. M., Yehia F. Z., Eissa A. M. F., Moustafa M. E., Eshaq G., Rabie A. M., ElMetwally A. E.: Cuand $\mathrm{Zn}$-acetate-containing ionic liquids as catalysts for the glycolysis of poly(ethylene terephthalate). Polymer Degradation and Stability, 110, 364-377 (2014). DOI: $10.1016 /$ j.polymdegradstab.2014.10.005 
[196] Atta A. M., Abdel-Rauf M. E., Maysour N. E., AbdulRahiem A. M., Abdel-Azim A. A. A.: Surfactants from recycled poly (ethylene terephthalate) waste as water based oil spill dispersants. Journal of Polymer Research, 13, 39-52 (2006).

DOI: $10.1007 / \mathrm{s} 10965-005-9003-0$

[197] Atta A. M., El-Kafrawy A. F., Aly M. H., Abdel-Azim A. A. A.: New epoxy resins based on recycled poly (ethylene terephthalate) as organic coatings. Progress in Organic Coatings, 58, 13-22 (2007). DOI: 10.1016/j.porgcoat.2006.11.001

[198] Fukushima K., Coulembier O., Lecuyer J. M., Almegren H. A., Alabdulrahman A. M., Alsewailem F. D., McNeil M. A., Dubois P., Waymouth R. M., Horn H. W., Rice J. E., Hedrick J. L.: Organocatalytic depolymerization of poly(ethylene terephthalate). Journal of Polymer Science Part A: Polymer Chemistry, 49, 1273 1281 (2011).

DOI: $10.1002 /$ pola.24551

[198] Krehula L. K., Hrnjak-Murgić Z., Jelenčić J., Andričić B.: Evaluation of poly(ethylene-terephthalate) products of chemical recycling by differential scanning calorimetry. Journal of Polymers and the Environment, 17, 20-27 (2009).

DOI: $10.1007 / \mathrm{s} 10924-009-0121-3$

[200] Bartolome L., Imran M., Lee K. G., Sangalang A., Ahn J. K., Kim D. H.: Superparamagnetic $\gamma-\mathrm{Fe}_{2} \mathrm{O}_{3}$ nanoparticles as an easily recoverable catalyst for the chemical recycling of PET. Green Chemistry, 16, 279-286 (2014).

DOI: $10.1039 / \mathrm{c} 3 g c 41834 \mathrm{k}$

[201] Fukushima K., Coady D. J., Jones G. O., Almegren H. A., Alabdulrahman A. M., Alsewailem F. D., Horn H. W., Rice J. E. Hedrick J. L.: Unexpected efficiency of cyclic amidine catalysts in depolymerizing poly(ethylene terephthalate). Journal of Polymer Science Part A: Polymer Chemistry, 51, 1606-1611 (2013). DOI: $10.1002 /$ pola.26530

[202] Katoch S., Sharma V., Kundu P. P.: Synthesis and characterization of saturated polyester and nanocomposites derived from glycolyzed PET waste with varied compositions. Bulletin of Materials Science, 36, 277-286 (2013).

DOI: 10.1007/s12034-013-0459-y

[203] Duque-Ingunza I., López-Fonseca R., de Rivas B., Gutiérrez-Ortiz J. I.: Synthesis of unsaturated polyester resin from glycolysed postconsumer PET wastes. Journal of Material Cycles and Waste Management, 15, 256-263 (2013). DOI: $10.1007 / \mathrm{s} 10163-013-0117-\mathrm{x}$

[204] Duque-Ingunza I., López-Fonseca R., de Rivas B., Gutiérrez-Ortiz J. I.: Process optimization for catalytic glycolysis of post-consumer PET wastes. Journal of Chemical Technology and Biotechnology, 89, 97-103 (2014)

DOI: $10.1002 /$ jctb. 4101
[205] Chen C-H., Chen C-Y., Lo Y-W., Mao C-F., Liao WT.: Studies of glycolysis of poly(ethylene terephthalate) recycled from postconsumer soft-drink bottles. II. Factorial experimental design. Journal of Applied Polymer Science, 80, 956-962 (2001).

DOI: 10.1002/app.1176

[206] López-Fonseca R., Duque-Ingunza I., de Rivas B., Arnaiz S., Gutiérrez-Ortiz J. I.: Chemical recycling of post-consumer PET wastes by glycolysis in the presence of metal salts. Polymer Degradation and Stability, 95, 1022-1028 (2010).

DOI: $10.1016 /$ j.polymdegradstab.2010.03.007

[207] Viana M. E., Riul A., Carvalho G. M., Rubira A. F., Muniz E. C.: Chemical recycling of PET by catalyzed glycolysis: Kinetics of the heterogeneous reaction. Chemical Engineering Journal, 173, 210-219 (2011). DOI: $10.1016 /$ j.cej.2011.07.031

[208] Zahedi A. R., Rafizadeh M., Taromi F. A.: Optimizing synthesis of PET oligomers end capped with phthalic/ maleic anhydride via recycling of off grade PET using design of experiments. Journal of Thermoplastic Composite Materials, 27, 1256-1277 (2014).

DOI: $10.1177 / 0892705712470266$

[209] Chen F., Yang F., Wang G., Li W.: Calcined Zn/Al hydrotalcites as solid base catalysts for glycolysis of poly(ethylene terephthalate). Journal of Applied Polymer Science, 131, 41053/1-41053/10 (2014).

DOI: $10.1002 / a p p .41053$

[210] Chaudhary S., Surekha P., Kumar D., Rajagopal C., Roy P. K.: Microwave assisted glycolysis of poly(ethylene terepthalate) for preparation of polyester polyols. Journal of Applied Polymer Science, 129, 2779-2788 (2013). DOI: $10.1002 /$ app.38970

[211] Goje A. S., Mishra S.: Chemical kinetics, simulation, and thermodynamics of glycolytic depolymerization of poly(ethylene terephthalate) waste with catalyst optimization for recycling of value added monomeric products. Macromolecular Materials and Engineering, 288, 326-336 (2003).

DOI: $10.1002 /$ mame.200390034

[212] López-Fonseca R., Duque-Ingunza I., de Rivas B., Flores-Giraldo L., Gutiérrez-Ortiz J. I.: Kinetics of catalytic glycolysis of PET wastes with sodium carbonate. Chemical Engineering Journal, 168, 312-320 (2011). DOI: 10.1016/j.cej.2011.01.031

[213] Aguado A., Martínez L., Becerra L., Arieta-araunabeña M., Arnaiz S., Asueta A., Robertson I.: Chemical depolymerisation of PET complex waste: Hydrolysis vs. glycolysis. Journal of Material Cycles and Waste Management, 16, 201-210 (2014). DOI: $10.1007 / \mathrm{s} 10163-013-0177-\mathrm{y}$ 
[214] Alnaqbi M. A., Mohsin M. A., Busheer R. M., Haik Y.: Microwave assisted glycolysis of poly(ethylene terephthalate) catalyzed by 1-butyl-3-methylimidazolium bromide ionic liquid. Journal of Applied Polymer Science, 132, 41666/1-41666/7 (2015). DOI: $10.1002 / A P P .41666$

[215] Saint-Loup R., Robin J-J.: Synthesis of poly[(ethylene terephthalate)-co-(E-caprolactone)]-poly(propylene oxide) block copolyester by direct polyesterification of reactive oligomers. Macromolecular Chemistry and Physics, 206, 1190-1198 (2005).

DOI: $10.1002 / \mathrm{macp} .200500079$

[216] Saint-Loup R., Robin J-J., Boutevin B., Argalon M., Michel A.: Synthesis of hydroxytelechelic $\varepsilon$-caprolactone/poly(ethylene terephthalate) co-oligomers, 1. Macromolecular Chemistry and Physics, 203, 12491256 (2002).

DOI: 10.1002/1521-3935(200206)203:9<1249::AIDMACP1249>3.0.CO;2-J

[217] Saint-Loup R., Jeanmaire T., Robin J-J., Boutevin B.: Synthesis of (polyethylene terephthalate/polyє-caprolactone) copolyesters. Polymer, 44, 3437-3449 (2003). DOI: $10.1016 / \mathrm{S} 0032-3861(03) 00257-X$

[218] Saint-Loup R., Robin J-J., Boutevin B.: Synthesis of poly(ethylene terephthalate)-block-poly(tetramethylene oxide) copolymer by direct polyesterification of reactive oligomers. Macromolecular Chemistry and Physics, 204, 970-982 (2003).

DOI: $10.1002 / \mathrm{macp} .200390072$

[219] Colomines G., Rivas F., Lacoste M-L., Robin J-J.: Study of polyurethane formulations containing diols obtained via glycolysis of poly(ethylene terephthalate) (PET) by oligoesters diols through a reactive extrusion process. Macromolecular Materials and Engineering, 290, 710-720 (2005).

DOI: $10.1002 /$ mame.200400391

[220] Achilias D. S., Redhwi H. H., Siddiqui M. N., Nikolaidis A. K., Bikiaris D. N., Karayannidis G. P.: Glycolytic depolymerization of PET waste in a microwave reactor. Journal of Applied Polymer Science, 118, 3066-3073 (2010).

DOI: $10.1002 / a p p .32737$

[221] Lu M., Kim S.: Unsaturated polyester resins based on recycled PET: Preparation and curing behavior. Journal of Applied Polymer Science, 80, 1052-1057 (2001). DOI: 10.1002/app.1189

[222] Mansour S. H., Abd-El-Messieh S. L., Ikaldious N. E.: Utilization of some oligomers based on poly(ethylene terephthalate) wastes as modifiers for polyvinyl chloride. Journal of Applied Polymer Science, 85, 25012509 (2002).

DOI: $10.1002 / a p p .10608$

[223] Tawfik M. E., Eskander S. B.: Chemical recycling of poly(ethylene terephthalate) waste using ethanolamine, sorting of the end products. Polymer Degradation and Stability, 95, 187-194 (2010).

DOI: $10.1016 /$ j.polymdegradstab.2009.11.026
[224] More A. P., Kute R. A., Mhaske S. T.: Chemical conversion of PET waste using ethanolamine to bis(2-hydroxyethyl) terephthalamide (BHETA) through aminolysis and a novel plasticizer for PVC. Iranian Polymer Journal, 23, 59-67 (2014).

DOI: $10.1007 / \mathrm{s} 13726-013-0200-0$

[225] Achilias D. S., Tsintzou G. P., Nikolaidis A. K., Bikiaris D. N., Karayannidis G. P.: Aminolytic depolymerization of poly(ethylene terephthalate) waste in a microwave reactor. Polymer International, 60, 500-506 (2011).

DOI: $10.1002 /$ pi.2976

[226] Dutt K., Soni R. K.: Synthesis and characterization of bis-amino ethyl terephthalamide from PET waste and its applications as hardener in DGEBA. International Journal of Plastics Technology, 18, 16-26 (2014). DOI: $10.1007 / \mathrm{s} 12588-014-9071-2$

[227] Jain A., Soni R. K.: Spectroscopic investigation of end products obtained by ammonolysis of poly (ethylene terephthalate) waste in the presence of zinc acetate as a catalyst. Journal of Polymer Research, 14, 475-481 (2007).

DOI: $10.1007 / \mathrm{s} 10965-007-9131-9$

[228] Mittal A., Soni R. K., Dutt K., Singh S.: Scanning electron microscopic study of hazardous waste flakes of polyethylene terephthalate (PET) by aminolysis and ammonolysis. Journal of Hazardous Materials, 178, 390-396 (2010). DOI: $10.1016 /$ j.jhazmat.2010.01.092

[229] Mir Mohamad Sadeghi G., Shamsi R., Sayaf M.: From aminolysis product of PET waste to novel biodegradable polyurethanes. Journal of Polymers and the Environment, 19, 522-534 (2011).

DOI: $10.1007 / \mathrm{s} 10924-011-0283-7$

[230] Padhan R. K., Gupta A. A., Badoni R. P. Bhatnagar A. K.: Poly(ethylene terephthalate) waste derived chemicals as an antistripping additive for bitumen - An environment friendly approach for disposal of environmentally hazardous material. Polymer Degradation and Stability, 98, 2592-2601 (2013).

DOI: $10.1016 /$ j.polymdegradstab.2013.09.019

[231] Parab Y. S., Shukla S. R.: Microwave synthesis and antibacterial activity of 1,4-bis (5-aryl-1,3,4-oxadiazole-2-yl) benzene derivatives from terephthalic dihydrazide obtained through aminolysis of PET bottle waste. Waste and Biomass Valorization, 4, 23-27 (2013).

DOI: $10.1007 / \mathrm{s} 12649-012-9128-4$

[232] Shukla S. R., Harad A. M.: Aminolysis of polyethylene terephthalate waste. Polymer Degradation and Stability, 91, 1850-1854 (2006).

DOI: $10.1016 /$ j.polymdegradstab.2005.11.005

[233] Soni R. K., Singh S.: Synthesis and characterization of terephthalamides from poly(ethylene terephthalate) waste. Journal of Applied Polymer Science, 96, 15151528 (2005).

DOI: $10.1002 / \mathrm{app} .21502$ 
[234] Spychaj T., Paszun D.: New trends in chemical recycling of poly(ethylene terephthalate). Macromolecular Symposia, 135, 137-145 (1998).

DOI: $10.1002 /$ masy. 19981350116

[235] Hoang C. N., Dang Y. H.: Aminolysis of poly(ethylene terephthalate) waste with ethylenediamine and characterization of $\alpha, \omega$-diamine products. Polymer Degradation and Stability, 98, 697-708 (2013).

DOI: $10.1016 /$ j.polymdegradstab.2012.12.026
[236] Geyer B., Röhner S., Lorenz G., Kandelbauer A.: Synthesis of ethylene terephthalate and ethylene naphthalate (PET-PEN) block-co-polyesters with defined surface qualities by tailoring segment composition. Journal of Applied Polymer Science, 131, 40731/140731/15 (2014).

DOI: $10.1002 /$ app.40731

[237] Röhner S., Dettinger U., Geyer B., Kandelbauer A., Gadon S., Egelhaaf H., Chassé T., Lorenz G.: Mechanical and optical properties of nanofunctionalized random block-co-polyesters of polyethylene terephthalate (PET) and polyethylene naphthalate (PEN). Journal of Applied Polymer Science, submitted (2016). 